\title{
New Order and Dayak marginalization (1966-1998)
}

This chapter will look at the political, economic and cultural marginalization of Dayaks under the New Order regime. In politics, the Dayak bureaucratic elite faced obstacles to promotion to strategic positions and did not occupy any strategic positions in the government. Their economic conditions did not improve as rapidly as would be commensurate with the scope of development projects into their regions. In fact, the development programs such as logging, plantation operations and transmigrations brought negative effects that impaired the economic status of the Dayaks. They suffered from a continuing lack of access to economic opportunities in urban areas as well as the impact of external and internal pressures on Dayak culture.

\section{MARGINALIZATION IN THE EXEGUTIVE}

After the coming of the New Order, Dayak leadership at the provincial and district levels disappeared. The Dayak governor and four district heads were replaced as the new regime did not have full confidence in them. As explained in the previous chapter, many Dayaks in government offices were members of the former Partindo. High-ranking Dayak bureaucrats from non-leftist backgrounds did not have the qualifications required by the regime. ${ }^{1}$ The regime, for example, did not support the nomination of Palaunsoeka as the governor to replace Oeray. ${ }^{2}$ Careers of other former high-ranking officials sympathetic to the Partai Katolik, such as H.S. Massoeka Djanting, also stagnated. Although Djanting had held important positions as a member of the DPD and BPH in the late

\footnotetext{
1 Positions regarded as high ranking are executive heads and their deputies, assistant governors, regional secretaries and, heads of departments and bureaus.

2 Interview with Mgn; Doera 2003:122.
} 
1950s and the early 1960s, and had reached a very senior ranking before being sidelined by Oeray, he was appointed only as a regular staff member at the provincial printing company until his retirement in the 1980 s. $^{3}$

During the New Order reign, the absence of Dayaks in high office was particularly obvious at the provincial level. According to provincial government documents, from 1977 to 1988 the percentage of highranking Dayak officials had never been more than 8 per cent. This contrasted sharply with the number of high-ranking Malay officials, which was always well above 30 per cent. No Dayak ever served as governor or assistant governor. Prior to the New Order, in contrast, the governor was a Dayak, and Dayaks had become members of councils, such as DPD and $\mathrm{BPH}$, which had functions similar to those of assistant governor. From the late 1950s to the mid-1960s, Dayaks always had at least two members in the executive council to assist or even represent the governor. Most districts also had two Dayak executive members. ${ }^{4}$

\begin{tabular}{|l|c|c|c|}
\hline Year & Total Positions & Dayaks & $\begin{array}{c}\text { Dayaks } \\
\text { (Percentage) }\end{array}$ \\
\hline 1977 & 48 & 1 & 2.1 \\
\hline 1979 & 62 & 2 & 3.2 \\
\hline 1983 & 69 & 3 & 4.4 \\
\hline 1988 & 79 & 6 & 7.6 \\
\hline
\end{tabular}

Table 6.1 Dayak high-ranking officials (1977-1988)

Source: Sejarah perkembangan pemerintahan 1978, 1980, 1983, 1989.

Dayaks were scarce in strategic bureaus or departments such as governance and human resources. In 1983 the governance bureau, which was probably the most influential body within the provincial secretariat, had only one Dayak out of 35 officials. ${ }^{5}$ The Human Resources Office,

3 H.M. Baroamas Jabang Balunus, 'Kedatangan dan penyebaran agama Katolik di tanah Kalimantan', n.y., pp. 51-2, in: Collection of H.M. Baroamas Jabang Balunus, Pontianak.

4 The last Dayaks in the BPH at provincial level were H.G. Mihing and Sotorman Benteng. Mihing was arrested in early 1971 because of his ties with Baperki, while Benteng resigned in 1972, after the BPH ceased to function (Abdulsalam 1997:97-8).

5 Jimmi M. Ibrahim, 'Memori Asisten I Sekwilda Tingkat I Kalimantan Barat', 1983, pp. 14-6, in: Library of West Kalimantan Governor's Office, Pontianak. 
which had the authority to specify training requirements for promotion, remained almost without Dayak officials until the mid-1990s. ${ }^{6}$ One Dayak was briefly appointed to head the employee development section at the Human Resources Office in April 1994. However, in less than a year, Simon Djalil, the officer concerned, was promoted away from the Human Resources Office. Almost a decade later, one Malay highranking official accused Djalil of giving preferential treatment to Dayak civil servants to attend training required for promotion. ${ }^{7}$ This anxiety could well be the reason behind his short stay. In June 1996 only one of 19 positions at the Human Resources Office was given to a Dayak, Ignatius Lyong. ${ }^{8}$

Dayaks were similarly marginalized at the district and sub-district levels. A few retained relatively high positions during the early New Order. A.R. Sampe and Iman Kalis, the first two Dayak senior high school graduates, served as district secretary (sekda) in Sambas and Sanggau districts respectively. At district level, a sekda is the third highest-ranking official after the district head and the deputy. P.J. Denggol, a former mission worker who had risen to a higher position in the bureaucracy of Ketapang district, was appointed caretaker district head of Ketapang in July 1971 after the sudden death of the incumbent district head. However, he only held that position for a year before being replaced by the local Kodim commander, Lieutenant-Colonel Zainal Arifin, who was elected district head in July 1972.

A local investigation in 1999 showed that Sintang, Kapuas Hulu, and Ketapang districts had only four Dayaks in high-ranking positions in each district, while Pontianak and Sanggau districts had only two each. There were no Dayak high-ranking officials in Sambas district and Pontianak municipality (KR 1999/43:33). The number of Dayak sub-district heads in the 1970s was smaller than in the 1960s. Prior to 1966, a former subdistrict head in Kapuas Hulu counted eight Dayak sub-district heads in fifteen sub-districts, or around 53 per cent of the total sub-district head

\footnotetext{
6 One Dayak source even claimed that Dayaks who were given opportunities to study further at the Institute of Public Administration (IIP) were placed in non-essential programs. The graduates from these non-essential programs would be put at a disadvantage if they had to compete with graduates from essential programs for important positions (interview with Djn).

Interview with Djp.

'Data pejabat', 1996, in: Biro Kepegawaian Kalimantan Barat, Pontianak. After the fall of the New Order, Lyong was appointed head of the provincial human resource office, then assistant of the governor. He resigned from the job and participated in the gubernatorial election in 2007, where he was running as a deputy governor candidate.
} 
positions. ${ }^{9}$ This number was reduced to six in 1978 (40 per cent of total sub-district head positions), and down to only three in 1998 (19 per cent). In Sanggau district in 1970, Dayaks still headed nine out of twenty subdistricts (45 per cent) but only six in 1978 (30 per cent) and four in 1998 (20 per cent). Similarly, in Sintang district, Dayaks comprised six of the eighteen sub-district heads (33 per cent) in 1970, but only three in 1978 and 1998 (17 per cent). Until the end of the New Order, the proportion of Dayak sub-district heads in the province never exceeded the 1971 level of 33 per cent, ${ }^{10}$ despite the fact that Dayaks constituted the majority in more than 61 per cent of sub-districts in the province.

\begin{tabular}{|l|c|c|c|c|c|}
\hline District & $\begin{array}{c}\text { Number } \\
\text { of sub- } \\
\text { districts } \\
(\mathbf{A})\end{array}$ & $\begin{array}{c}\text { Number } \\
\text { of Dayak } \\
\text { sub-district } \\
\text { heads } \\
(\mathbf{B})\end{array}$ & $\begin{array}{c}\text { Percentage } \\
\text { of Dayak } \\
\text { sub-district } \\
\text { heads } \\
\text { (B/A) }\end{array}$ & $\begin{array}{c}\text { Percentage } \\
\text { of Dayak } \\
\text { sub-district } \\
\text { heads }\end{array}$ & $\begin{array}{c}\text { Percentage } \\
\text { of sub- } \\
\text { districts } \\
\text { with Dayak } \\
\text { majority }\end{array}$ \\
\hline $\begin{array}{l}\text { Pontianak } \\
\text { City }\end{array}$ & - & - & - & - & - \\
\hline Pontianak & 19 & 5 & 26.3 & 42.1 & 56.5 \\
\hline Sambas & 17 & 4 & 23.5 & 35.3 & 42.1 \\
\hline Sanggau & 20 & 4 & 20.0 & 40.0 & 90.9 \\
\hline Sintang & 18 & 3 & 16.7 & 22.2 & 85.7 \\
\hline $\begin{array}{l}\text { Kapuas } \\
\text { Hulu }\end{array}$ & 16 & 3 & 18.8 & 18.8 & 56.5 \\
\hline Ketapang & 14 & 2 & 14.3 & 7.1 & 40.0 \\
\hline
\end{tabular}

Table 6.2 Dayak sub-district heads (1998-1999)

Source: Camat se-Kalbar 1998; KR 1999/43.

Various employee databases at the provincial and district levels showed similar trends: the number of Dayak civil servants was either very small or not proportional with the Dayak population. Of 728 provincial midto top-level civil servants in 1999, Dayaks made up no more than 8 per

$9 \quad$ Interview with Syk.

1o The calculation in 1971 excluded Kapuas Hulu, for which data were not available. 


\begin{tabular}{|l|c|c|c|c|c|}
\hline District & Total sub- & \multicolumn{5}{|c|}{ Number sub-district with } \\
\cline { 3 - 6 } & & $\begin{array}{c}\text { Malays > 50 } \\
\text { districts }\end{array}$ & $\begin{array}{c}\text { Dayaks > 50 } \\
\text { (percentage) }\end{array}$ & $\begin{array}{c}\text { Dayaks > }> \\
\text { (palays }\end{array}$ & $\begin{array}{l}\text { Malays > } \\
\text { Dayaks }\end{array}$ \\
\hline Pontianak City & 4 & 0 & 0 & 0 & 1 \\
\hline Sambas & 9 & 8 & 1 & 1 & 8 \\
\hline Bengkayang & 7 & 0 & 5 & 6 & 1 \\
\hline Singkawang & 3 & 0 & 0 & 1 & 2 \\
\hline Pontianak & 13 & 1 & 1 & 3 & 10 \\
\hline Landak & 10 & 0 & 9 & 10 & 0 \\
\hline Sanggau & 15 & 0 & 12 & 14 & 1 \\
\hline Sekadau & 7 & 0 & 4 & 7 & 0 \\
\hline Sintang & 14 & 0 & 9 & 13 & 1 \\
\hline Melawi & 7 & 3 & 1 & 4 & 3 \\
\hline Kapuas Hulu & 23 & 9 & 11 & 13 & 10 \\
\hline Ketapang & 15 & 7 & 4 & 6 & 9 \\
\hline Total & 127 & 28 & 57 & 78 & 46 \\
\hline Percentages & & 22 & 44.9 & 61.4 & 36.2 \\
\hline
\end{tabular}

Table 6.3 Number of sub-districts with a Dayak or Malay majority (2000) Source: Census 2000.

cent, while Malays were estimated to represent at least 50 per cent. ${ }^{11}$ In Sanggau district, a study by a former local Dayak official in 2003 found that Dayaks constituted only 12.3 per cent of the total 1,146 civil servants in the district. ${ }^{12}$ This was despite the fact that Sanggau had a Dayak population of 62 per cent. In the coastal district, the percentage

11 'Data pejabat struktural di lingkungan Setwilda Tingkat I Kalimantan Barat, komponen Departemen Dalam Negeri, Dinas Daerah Tingkat I Kalimantan Barat, disusun oleh Bagian Pengembangan Pegawai Biro Kepegawaian', 1999, in: Library of West Kalimantan Governor's Office, Pontianak.

12 Hironimus Oemar, 'Daftar keadaan PNS Dayak dan non Dayak pada Sekretariat Daerah, Sekretariat Dewan, dinas, badan dan kantor pada Pemda Kabupaten Sanggau', 2003, in: Collection of Hironimus Oemar, Sanggau. The same person conducted a similar survey in September 1998. He found that at the district level, Dayaks represented 13.8 per cent of the 617 employees. The percentage was higher at the sub-district level where the Dayaks were 57.3 per cent of 367 civil servants (KR 2000/53:10). While neither study indicated the ethnic background of the remaining civil servants, it was quite safe to assume that the majority of them were Malays, because Malays had worked in the civil service since colonial times. 
of Dayaks in the bureaucracy was even lower. The following will examine the reasons behind the small number of Dayaks in the executive.

\section{ORIGINS OF MARGINALIZATION OF THE DAYAKS IN THE EXECUTIVE}

The role of Dayaks in the bureaucracy had been very small if not non-existent prior to 1945 . Dayaks were generally excluded from the sultanate administrations because recruitment was determined by social class, family ties, and religion. Opportunities for Dayaks to work in the Dutch administration offices were also limited. The Dutch government did not want to upset its relations with the sultanates unnecessarily by appointing the 'infidel' Dayaks whom the sultanates might have deemed unsuitable. Furthermore, the educational level of Dayaks was still too low to allow them to fill good positions in the colonial administration. Generally, a civil service candidate would be at least a graduate from a Hollandsch-Inlandsche School (HIS), a Dutch-language or first-class elementary school reserved for aristocratic and wealthy families. ${ }^{13}$ Given the Dayaks' early lukewarm attitude toward education, the social stigma against the Dayaks, and the cost and time needed to attend schools in town, it was unlikely that any Dayaks had ever enrolled at an HIS. ${ }^{14}$ In fact, none of my senior Dayak informants graduated from an HIS, nor did they know of any colleagues who had graduated from the school prior to WWII.

Following of World War II, Dayaks began to have access to bureaucratic positions by means of government support. After the elections in 1955 and 1958, when the PD outperformed most of the other political parties, Dayaks began to assume some important political posts, including governor and four district head positions. This was followed by the

13 Syahzaman and Hasanuddin 2003:127; Vandenbosch 1941:200. One source claimed that the schools in West Kalimantan were likely not based on social class because entry requirements were looser (Ahok et al. 1983:49-50). This flexibility in entry requirements, although possibly true for the Malays, was unlikely to have been applied to the Dayaks due to the social bias.

${ }_{14}$ By 1924 the whole province only had three HIS, one each in Pontianak, Sintang, and Sambas (Halilintar, 2-2-1924). The HIS in West Kalimantan was known as 'Sekolah Melayu' (Malay School) as the teaching was conducted in the Malay language. While the similar term 'Sekolah Melayu' was used elsewhere, it carried extra ethnic weight in West Kalimantan as the term 'Melayu' also referred to the governing ethnic group in this region. 
appointment of a number of Dayak sub-district heads in predominantly Dayak regions from the late 1950 s to mid-1960s. ${ }^{15}$

Dayaks in top positions could facilitate Dayak civil service recruitment. A former Dayak head of several sub-districts in Sanggau from 1960 to 1964 remarked that until mid-1965, sub-district heads could recruit employees with approval from just district heads. The source gave examples:

- From May 1960, as the sub-district head of Belitang, he had recruited six new staff members, five of whom were Dayaks; the incumbent five staff members were all Malays.

- From July 1963 as the sub-district head of Jangkang, he had recruited three new Dayak employees. The existing five employees consisted of four Malays and one Dayak.

- In May 1964, he became the head of the newly formed Parindu subdistrict. There, he recruited ten staff members - eight Dayaks and two Malays. ${ }^{16}$

There were also efforts to boost the number of Dayak civil servants through other channels of recruitment, such as the Civil Service Institute (KDC, Kursus Dinas G). The institute, established in October 1961, recruited 28 to 30 students each year until 1964. ${ }^{17}$ The first recruitment round in 1961 included only one Dayak, but their number increased in subsequent enrolments. In 1963 there were six Dayaks, and in 1964 there were ten. ${ }^{18}$ According to one Malay source, who was also a student at KDC during those years, one way to improve the recruitment of Dayaks was to bend the admission rules in a way that enabled more Dayaks to be accepted into the institute. ${ }^{19}$ The source claimed that the enrolment rule was bent to accommodate those who graduated from teacher training schools, such as Sekolah Guru Bawah (SGB) and Sekolah Guru Atas (SGA). Dayak bureaucrats in the government knew that most Dayaks

\footnotetext{
15 The appointments of sub-district heads at the end of the 1950s were influenced by the political strength of each party at that time. If PD performed well in a certain sub-district, it could nominate the candidate for the sub-district head (interviews with Bln and Mgk).

16 Interview with Omr. The Dayak head of the Human Resources Office in Sanggau district also supported affirmative action in the recruitment of the Dayaks (interview with Amt).

17 The total number of KDC graduates until its closure in 1965 was 119 (Ahok et al. 1983:85).

18 Interviews with Gye and Fhd; Meletakkan landasan 1997:135-9.

19 Interview with Djp.
} 
attended these schools, rather than general high schools. ${ }^{20}$ The original rule was only to accept graduates from general high schools or graduates from junior high schools with two years' working experience in the bureaucracy. $^{21}$

When KDC was upgraded to become a three-year civil service institute (APDN, Akademi Pemerintahan Dalam Negeri) in September 1965, Tanting Ngo, a Dayak, was appointed to run the institute. ${ }^{22}$ His appointment was without controversy. Recruited in October 1964 just after graduating from university, he was appointed as deputy head of the political bureau at the governor's office and, most importantly, as a private secretary to Oevaang Oeray. ${ }^{23}$ For Oeray this Dayak appointment to a critical position was very likely a strategy to increase Dayak enrolments at the Institute. However, most of Tanting Ngo seven-month tenure was ineffective because of the political chaos after the coup in 1965. Nevertheless, Ngo still claimed to have helped a few Dayaks gain entry to the institute with only approval from the governor. Probably because of this practice, during the demonstration against Oeray's leadership APDN was dubbed the 'APDN of Oevaang Oeray and Tanting Ngo'.24 Oeray was pressured to remove Ngo in May 1966 (Abdulsalam 1997:79).

Despite efforts from the end of the 1950s to the mid-1960s to recruit Dayaks, the number of Dayak civil servants remained small, and the bureaucracy was still largely in the hands of the Malays. This dominance continued despite changes in the regime and political systems. Each time a regime collapsed, the majority of the civil service from the previous regime would continue to serve the new regime.

Almost all Dayak civil servants who entered the bureaucracy immediately after independence had only basic schooling - three to six years' elementary education, which they obtained through mission schools.

\footnotetext{
20 Interview with Djp. The author was able to trace only a few SGA or SGB graduates in KDC, and therefore was not able to substantiate the claim.

${ }^{21}$ Jimmy M. Ibrahim, 'Laporan direktur Akademi Pemerintahan Dalam Negeri Pontianak Lustrum ke-1’, 1970, p. 9, in: Library of West Kalimantan Governor's Office, Pontianak.

${ }_{22}$ The first director of Pontianak APDN was actually Raden Kusno. However, it was the deputy director, Tanting Ngo, who ran the institute, because Kusno was only a figurehead (interview with Ttg; Jimmi M. Ibrahim, 'Laporan direktur Akademi Pemerintahan Dalam Negeri Pontianak Lustrum ke-1', 1970, p. 11, in: Library of West Kalimantan Governor's Office, Pontianak; Abdulsalam 1997:77).

23 Alfonsus Jacobus Tanting Ngo, 'Daftar pertanjaan "clearance test"', 1970, in: Collection of Alfonsus Jacobus Tanting Ngo, Pontianak. Oeray knew Tanting Ngo, an East Kalimantan Dayak, who studied at the same school in Yogyakarta as his adopted son (interview with Ttg). He was the first Dayak law graduate in West Kalimantan, and probably the first Dayak with a full bachelor's degree in the province. ${ }_{24}$ Interview with Ttg.
} 
Those educated from the end of 1940s, because of the expansion of primary education for the Dayaks, only started to graduate from the early to mid-1950s. Consequently, these Dayaks were ready to enter the civil service from that time on. During this transition period, Malays were more likely to be recruited when vacancies occurred due to their earlier access to education and their 'connections' with the bureaucracy.

Educational requirements to enter the bureaucracy continued to rise as numbers of more highly educated candidates became available. Again, Dayaks were comparatively slow to catch up because of their late start. In 1953, there were only two Dayak senior high school graduates, Iman Kalis and A.R. Sampe, for all of West Kalimantan. Those who were already employed in the bureaucracy but who had only primary education missed out on promotions.

The limited number of high schools and the often inaccessible locations of schools were among the reasons why there were only a small number of Dayak graduates. Pontianak, the provincial capital, opened its first junior high school in 1946 and first senior high school in 1952. ${ }^{25}$ Between 1946 and 1948 about a dozen Dayaks enrolled at this junior high school. ${ }^{26}$ In interior districts, particularly the Dayak regions, secondary schools were not established until several years later. Sintang, for example, opened its first junior high school in 1951 and first senior high school in 1959 (Syahzaman and Hasanuddin 2003:166). Nyarumkop, the centre for Dayak education, opened its first general junior high school also in 1951 (Peringatan bruder MTB 1996:14).

Another reason for the small numbers of Dayak civil servants was their lack of interest in joining the bureaucracy. From the time of the Malay sultanates, Dayaks associated civil service with the Malays because of their overwhelming presence and influence in the bureaucracy. Civil service positions were the privilege of Malays and were closed to Dayaks (Van Hulten 1992; Van Loon 1999). Furthermore, the civil service, which had connections with the previously discriminatory sultanate administration, had a bad reputation among Dayaks. Therefore, civil service employment was not much sought by Dayaks who later went to

25 Interviews with Kls, Bln, Syk; Peringatan bruder MTB 1996:16.

26 Enrolled in 1946 were H.S. Massoeka Djanting and Antonius Buan; in 1947, Keladan, Iman Kalis and A.R. Sampe; in 1948 Syahdan Sahuddin, Sabinus, I. Andi, I. Kepu, and Daniel Soeryamassoeka. They all stayed in a church complex or in homes belonging to about 20 Dayak officials or civil servants in Pontianak (interviews Kls, Syk). 
schools. Instead, they would choose to work for the Catholic missions as teachers, religious workers, or nurses, as these were the only white-collar jobs open to them at the time. Not surprisingly Dayaks who assumed important posts after independence had previously been teachers, catechists, or nurses. These job preferences among the Dayaks continued well into the 1960s, particularly those for the teaching profession. Some sources observed that generally in the 1960s the educated Dayaks still preferred teaching posts over positions in the civil service. ${ }^{27}$ The first two Dayak high schools graduates, Kalis and Sampe, for example, became teachers and did not join the bureaucracy until the early $1960 \mathrm{~s} .{ }^{28}$ Dayaks who returned to the province after obtaining a university degree in Java in the mid-1960s also chose to continue their teaching careers and not join the bureaucracy. ${ }^{29}$ The sizeable number of Dayaks, who finally joined the bureaucracy in the early 1960s, such as those who attended the KDC, were mainly active educators who had been persuaded by Dayak bureaucrats to join the civil service.

\section{GIVIL SERVANT RECRUITMENT AND PROMOTION DURING THE NEW ORDER ERA}

Two major routes of civil servant recruitment were bonded and general annual recruitment. Bonded recruitment referred to students who enrolled at designated institutions and had agreed to become civil servants upon graduation. At least 68 institutes managed by government offices existed; part of their function was to educate the bonded students. ${ }^{30}$ Apart from these institutions, government offices also had agreements with certain universities for the same purpose. The government also established Civil Service Institutes to select and educate its future civil servants.

${ }^{27}$ Interviews Kdr, Kls. The passion to become teachers was also a result of an education campaign aimed at Dayaks after independence. The government, PD, and churches established hundreds of elementary schools in the 1940 s and 1950 s, which of course opened many teacher vacancies. Becoming a teacher was not only desirable in terms of prestige, but also in terms of government support and financial reward. Most students in the teacher schools received government scholarships, which covered tuition fees and living costs. Sources claimed that the salary of teachers was even better than those of civil servants (interviews Kdr, Kls).

28 Interview Kls.

29 In 1963, the West Kalimantan government sent 17 students to attend teacher institutes in Java. Among them at least six were Dayaks ('Laporan kerdja tahun 1963', 1964, in: Library of West Kalimantan Governor's Office, Pontianak).

so See http://www.pdat.co.id/pertiti/?called=pt (accessed 8-7-2004). 
Civil servants recruited via this avenue were highly regarded and normally had better career prospects, because of their specialized training. Until quite recently graduates of civil services institutes were usually expected to take on elite roles in the bureaucracy. Many graduates would at least occupy the position of sub-district heads within a few years after graduation. Their numbers in the bureaucracy had become a barometer for the quality of the bureaucracy. The West Kalimantan governor's accountability reports since establishment of the New Order always highlight the numbers and the utilization of graduates of the institutes.

As explained previously, the first Civil Service Institute in West Kalimantan was KDC. Prior to that, the provincial government sent their students to KDC in Banjarmasin, South Kalimantan. A courselevel KDC was replaced by a three-year university-level APDN, when the latter was established in Pontianak in 1965. Starting from the mid1960s, many KDC graduates were appointed as sub-district heads. In 1970, 24 of 106 sub-district heads (or 23 per cent) were APDN graduates. The percentage increased to 63 per cent in 1977, and to 79 per cent in $1983 .{ }^{31}$

Annual general recruitment at the provincial and district levels was another important recruitment channel. Usually it was carried out at the same time for both locations. Some departments that had a large intake of recruits, such as the Department for Religious Affairs, also carried out their own annual recruitment. All candidates would be screened against the general requirements, such as age, education, and health. Those who satisfied the requirements would need to pass a written examination and interview. The majority of civil servants recruited by this method would be appointed to clerical positions. The number of civil servants recruited this way was much larger than the recruitment from APDN. General recruitment could admit several hundred to a few thousand civil servants per year, compared to no more than sixty from Pontianak APDN.

According to one Dayak official, who was briefly stationed at the provincial Human Resources Office, the process of civil servant recruitment was not transparent. The written test and interviews were mere formali-

${ }^{31}$ 'Laporan umum Gubernur Kepala Daerah Propinsi Kalimantan Barat kepada menteri dalam negeri', 1970, p. 5, 'Kalbar membangun: Memori Kadarusno Gubernur Kepala Daerah Tingkat I Kalimantan Barat 1972-1977', 1977, p. 70, 'Peningkatan pembinaan pemerintahan, pembangunan dan kemasyarakatan di daerah Kalimantan Barat', 1983, pp. 54-5, in: Library of West Kalimantan Governor's Office, Pontianak. 
ties, because the office would only select a fraction of the candidates who had actually passed the test. Many other candidates were selected based on bribery and personal connections. ${ }^{32}$ As a result, candidates without the requisite financial resources and internal connections would seldom be recruited. ${ }^{33}$

Recruitment of Dayak civil servants through both systems was low throughout the New Order. Dayaks made up between 15 per cent and 20 per cent of APDN graduates from 1968 until 1992, while the Malays outnumbered the Dayaks by at least a factor of two (Meletakkan landasan 1997:135-69). This condition worsened after 1992 when all local APDNs were replaced by a national STPDN (Sekolah Tinggi Pemerintahan Dalam Negeri) located in Jatinangor, West Java. ${ }^{34}$ Between 1992 and 1997 West Kalimantan only sent about twelve students a year to STPDN, a big drop from about fifty students a year between 1965 and 1992 under the APDN system. Of these twelve students even fewer were Dayak (Meletakkan landasan 1997:127-69). Recruitment of Dayaks into the civil service through general annual recruitment was estimated at only 2 per cent each year (KR 1999/43:33). This estimation might be too low; however, if there had been a consistently significant recruitment of Dayaks into the bureaucracy over the years, their proportion in the bureaucracy should have increased, but this has not been the case. Civil servants in the lower to middle ranks were overwhelmingly Malays who occupied most posts that were not reserved for Javanese or the non-local military officers.

The causes of the low recruitment of Dayaks into the bureaucracy during the New Order differed slightly from those of the previous regime. The main factors for low recruitment in the 1950s had become less relevant by the time Soeharto came to power. By the 1970s, the Dayaks' interest in joining the civil service had grown, as evidenced by

$3^{2} \quad$ Interview Kts.

33 The public was aware of these corrupt practices but did not openly challenge them until 2002. Between October and November that year, candidates who failed the recruitment test protested in almost all districts. In Pontianak district, the recruitment results were annulled by the district head, and the written tests were re-administered. In Sintang, the Human Resources Office was attacked, and its Dayak head was brought to court for unfair practices (Kapuas Post, 13-11-2002, 25-3-2005). In both cases, the heads of the Human Resources Office were replaced some time after the protests.

34 The establishment of a central civil institute was important for the government's efforts to train high-quality and uniform future leaders. In 2005, STPDN became IPDN (Institut Pemerintahan Dalam Negeri) after it merged with another similar institute, IIP (Institut Ilmu Pemerintahan) in Jakarta, to avoid duplication (Kompas, 6-1-2005). 
the decision of many Dayak high school teachers to join the bureaucracy. The ascent of several Dayaks into the province and district top jobs prior to the New Order inspired young and educated Dayaks to join the civil service. They no longer viewed the civil service as intimidating and unattainable. Also, low levels of education, which had previously been an obstacle to Dayaks joining the civil service, were no longer an issue. The number of Dayak high school graduates was adequate at the beginning of the 1980s, and by the 1990s there should have been a sufficient supply of Dayak university graduates. Then, what could have restricted the Dayaks from entering the bureaucracy or stunted their careers in the bureaucracy during the New Order era?

The unfavourable political system was one reason. Before the ascent of the New Order the political system was relatively favourable to Dayaks. The national government respected natives' role in local government or at least it was not averse to the idea. This was reflected in the appointments of natives to governor and district head positions in the province. These Dayak officials, in turn, tried to encourage more Dayaks to join the bureaucracy. Many Dayak teachers were persuaded, and those with higher educational backgrounds were recruited directly to good positions. Take the case of Iman Kalis, one of the first two Dayak high school graduates. He graduated from senior high school in 1953 and became the headmaster of a junior high school in Sintang (1954-1957), and then Sanggau (1957-1958). He attended university in Yogyakarta from 1958 to 1963 . When he returned to West Kalimantan in 1963, he accepted an offer to become a district secretary in Sanggau. Quite similar was the case for A.R. Sampe who was recruited as secretary of Sambas district. ${ }^{35}$ Many Dayaks were appointed as sub-district heads although they might not have been the best qualified candidates for the position. This changed quite drastically after the New Order took power. The new regime was rather suspicious of Dayak civil servants, especially at the beginning of the regime. All Dayak executive heads were removed and when in the late 1960s many others in the upper echelons started to retire, these positions were not filled with Dayaks.

The regime's centralized and anti-ethnic approach prevented any preferential treatment of underprivileged Dayaks in the bureaucracy. No Dayak was appointed again as governor or district head until the 
end of the New Order, with only one exception in 1995. At lower levels, such as the appointment of sub-district heads, the regime was also not bound to appoint persons with the same ethnic or religious background as the majority population. Dayak elites in the bureaucracy were aware of the continuing prejudice against their own, but for their career and safety, did not antagonize this repressive regime. The repression of all political parties, including those with an interest in the Dayaks such as PK (and later PDI), ensured that issues of ethnicity and marginalization were never raised.

A few Dayak bureaucrats and politicians also believed that ethnic discrimination was a factor underlying their small representation in the bureaucracy. Some retired Dayak politicians believed that their small role in the bureaucracy, particularly at the beginning of the New Order regime, was a result of Malay reprisals. ${ }^{36}$ The two ethnic groups had had a hard time getting along in the past due to differences in their religion, culture, and political histories. From the not so distant past, at the end of the 1940s, elites from both ethnic groups opposed each other as to whether to support the unitary state or not. Malay and Dayak relations deteriorated when the Dayaks were able to gain certain top executive positions at the end of 1950s. Dayaks won the district head election in four districts, while the Malays won in only three districts. The governor was a Dayak. The Dayaks also started to fill up many sub-district head positions in interior Dayak regions, mostly at the expense of Malays. The sudden rise of Dayaks in the bureaucracy created resentment from the other ethnic groups who felt they were more capable and entitled to the work. In 1962 Oevaang Oeray was accused of practising ethnic partiality in employee recruitment and promotion. ${ }^{37}$

Quite commonly ethnic groups limit the entry of rival ethnic groups into the bureaucracy in order to maintain their domination. Malay bureaucrats did not find it difficult to block the Dayaks' entry or promotion because they dominated the bureaucracy. While the Malays did not necessarily occupy the highest positions, which were often reserved for the Javanese or non-native military officers, they were well represented in both district and provincial second-tier leadership, including filling positions like headships of important departments and bureaus responsible

\footnotetext{
$3^{6} \quad$ Interviews with Lyg and Mgk.

37 'Pokok: Permohonan pindah sdr. Mochtarroeddin, pedjabat wedana Putussibau ke kantor Gubernur Kepala Daerah Kalimantan Barat', 1962, in: Archive Office of West Kalimantan, Pontianak.
} 
for recruitment, such as the Civil Service Institute. ${ }^{38}$ Malay staff who dominated the lower level echelons could have played a significant role in limiting the Dayaks' entry because they prepared reports on which recruitment decisions were based and they were also the first to 'sort' the applications. Moreover, Dayak applicants also lacked financial resources (i.e. for paying bribes) as well as insider backing (i.e. from relatives).

As a consequence of the limited recruitment of Dayaks over the years, only a small pool of them was eligible for promotion. Furthermore, promotion became much more complicated and difficult if discrimination came into play. Some inside sources remarked that discrimination or personal bias affecting promotions was quite common. ${ }^{39}$ If this partiality was also true at the Promotion Board (Baperjakat), which handled high level promotion, then higher promotion for the Dayaks was slim. The board usually consisted of the executive heads and their deputies or assistants, the human resources head, and representatives of related departments or bureaus. As explained before, these strategic bureaus usually employed only a few Dayaks, and, until the mid-1990s had never been headed by Dayaks. It could be assumed that Dayak interests would receive little support within the council.

\section{MARGINALIZATION IN THE DPRD}

Dayak marginalization in the local legislative branch was quite conspicuous during the first decade of the New Order. Before the coming of the New Order, Dayaks were quite well represented in the legislature. In 1958, the percentage of Dayaks in the West Kalimantan provincial DPRD reached almost 37 per cent of the total DPRD members, the highest percentage ever. In interior districts such as Sanggau, Sintang, and Kapuas Hulu the proportion of Dayaks in the DPRD reached more than 50 per cent. The proportion declined slightly at the provincial level after 1961.40 Between 1966 and the 1977 election, the proportion of

$3^{8} \quad$ All APDN teachers in 1973 were non-Dayaks (Memorie serah terima 1973). Only later were some Dayaks appointed to teach at the institute (Meletakkan landasan 1997). All APDN directors after Tanting Ngo were Malays.

$39 \quad$ Interviews with Lyg and Ttg; Abdulsalam 1997.

$4^{\circ} \quad$ The main reason was the split of PD into two political parties - Partindo and PK. Although the majority of members in Partindo and PK were still Dayaks, non-Dayaks had started to assume some leadership roles in the parties, particularly at the provincial level. In the case of Partindo, some of these leaders became members of the provincial DPRD. To illustrate this case, three of seven Partindo representatives in the provincial DPRD in 1961 were non-Dayaks. The same was the case for PK. 
Dayaks in the provincial DPRD was very low - only between 11 and 13 per cent. The Dayaks were also poorly represented at the district level DPRD.

\begin{tabular}{|l|c|c|c|}
\hline Year & Total Seats & Number of Dayaks & Percentage of Dayaks \\
\hline 1957 & 30 & 9 & 30.0 \\
\hline 1958 & 30 & 11 & 36.7 \\
\hline 1961 & 31 & 7 & 22.6 \\
\hline 1967 & 48 & 6 & 12.5 \\
\hline 1970 & 52 & 6 & 11.5 \\
\hline 1971 & 40 & 5 & 12.5 \\
\hline 1977 & 40 & 7 & 17.5 \\
\hline 1982 & 40 & 10 & 25.0 \\
\hline 1987 & 45 & 12 & 26.7 \\
\hline 1992 & 45 & 15 & 33.3 \\
\hline 1999 & 55 & 16 & 29.1 \\
\hline 2004 & 55 & 12 & 21.8 \\
\hline
\end{tabular}

Table 6.4 Dayak legislators in the provincial DPRD (1957-2004)

Sources: 'Laporan kerdja tahun 1963', 1964, in: Library of West Kalimantan Governor's Office, Pontianak; Memori perkembangan 1992:119-30; and other sources.

The decline in Dayak representation in the legislature at the provincial and district levels occurring after 1966 was as a result of the new regime's blanket hostility and distrust of political parties, particularly former leftist parties or parties with ties to Soekarno. After 11 March 1966, the regime started to purge the national and regional assemblies of Communists. ${ }^{41}$ At the same time, the regime put more pro-regime members into the DPRD in order to balance the existing DPRD members. In West Kalimantan, the regime increased the total numbers in the DPRD but without increasing the number of Dayaks. In fact, in some regions the number of Dayak legislators had decreased after the Partindo

$4^{1}$ Regulations issued on 1-2-1966 and Law 20/1967 removed Communist representatives and sympathizers from the DPRD. 
merger with IPKI. As a result of these measures, their proportion in the DPRD fell.

The number of Dayak DPRD members reached its nadir after the 1971 election. The only district in which the share of Dayak legislators exceeded that of pre-1965 was the coastal Pontianak district. This was possible because Golkar, PK, and IPKI all sent significant numbers of Dayaks to the DPRD of the district. Golkar contributed seven seats, while PK and IPKI contributed five seats. Elsewhere, PK and IPKI gained only a few seats, while Golkar, the election winner, only sent a small number of Dayaks as their members of parliament. PK and IPKI, the main source of Dayak legislative candidates, as well as other political parties, were under pressure from the regime even before the election campaign began. IPKI became the main target because it was one of the largest political parties and therefore posed the most serious threat to Golkar. IPKI was also of particular interest to local authorities because it included many members from former leftist Partindo. Several IPKI legislative candidates originally the former Partindo party were eliminated by the military authority team during the process of selecting provisional candidate lists (DCS) for the 1971 election. The greatest IPKI election losses occurred in Sambas, Sanggau, Sintang, and Ketapang districts. ${ }^{42}$

During the 1971 election, the regime faced a dilemma with regard to several high profile candidates who were nominated by other political parties and therefore might undermine the regime's goal of a win for Golkar. The regime made a decision on 14 March 1971 to retain those candidates on in the list, but in low, non-electable positions under the closed-list proportional-representative system (Buku pemilihan umum 1973:239-40). In West Kalimantan, the military authority lowered some Dayak figures within IPKI to non-electable positions in the preliminary candidate list (DCS). Some affected figures were Oevaang Oeray, Petrus Anjiem, and Stephanus Thomba at the provincial level, and Paitijadi, Djohan Marpong, Sabran Simprong, and Rachmad Sahuddin in Pontianak district. ${ }^{43}$ Many of these names had disappeared when the final official list (DCT) was announced. In the provincial DCT Oeray,

$4^{2}$ 'Laporan Gubernur Kepala Daerah/ketua Panitia Pemilihan Daerah Tingkat I Kalimantan Barat', 1971, in: Library of West Kalimantan Governor's Office, Pontianak.

43 'Laporan Gubernur Kepala Daerah/ketua Panitia Pemilihan Daerah Tingkat I Kalimantan Barat', 1971, in: Library of West Kalimantan Governor's Office, Pontianak. 
Anjiem, and Thomba disappeared from the list of IPKI candidates. ${ }^{44}$ In other cases, the candidates were pressured by the military to withdraw their candidacies. Threats of jail terms from the military authority towards members of the opposition in inland areas were quite common during this transitional time. In one extreme case in Sintang district, none of the nine IPKI candidates on the provisional list appeared on the final list. ${ }^{45}$ Prior to the election in Ketapang, the head of the local branch of the IPKI declared the party to be no longer active. ${ }^{46}$

Faced with such threats and intimidation, no political parties could campaign properly. ${ }^{47}$ With a few exceptions, almost no election monitoring was done in interior regions. One political party leader in Sintang reported that no political parties, except Golkar campaigners, could campaign freely. Few political parties monitored the voting process because of the intimidation. ${ }^{48}$ IPKI and PK in particular lost many votes because they depended mainly on voters in interior districts, where election-rigging was most rampant. In coastal cities, pressure on the political parties was less severe. One observer linked to the Catholic Church, observed that the process in several polling stations in Pontianak City, the provincial capital, was relatively free and according to the regulations (Doera 2003:299-319). The different levels of intimidation from the local authorities in coastal and interior regions was evident when the polling results came out. In interior districts and Ketapang where threats and election rigging were more obvious, Golkar won an average of 77 per cent of the votes, while in coastal district capitals and provincial capitals, Golkar obtained fewer votes, with an average of 58 per cent. At the end, IPKI and PK, two political parties with significant Dayak votes, only obtained a few seats in the 1971 election.

Another reason for the decline in the number of Dayak legislators in the DPRD was that the Dayaks did not benefit from Golkar's landslide

\footnotetext{
44 'Himpunan kegiatan/aktivitas DPRD Propinsi Kalimantan Barat: Periode tahun 1971/1972 s/d 1972/1973', 1973, in: Library of West Kalimantan Governor's Office, Pontianak.

45 'Laporan Gubernur Kepala Daerah/ketua Panitia Pemilihan Daerah Tingkat I Kalimantan Barat', 1971, 'Daftar tjalon tetap anggota DPRD untuk Daerah Tingkat II Sintang', 1971, in: Library of West Kalimantan Governor's Office, Pontianak.

$4^{6} \quad$ Interview Smj.

47 Such political intimidation was not unique to West Kalimantan. Ward (1974:166) observed the similar trend in Java during the 1971 election.

$4^{8} \quad$ Interview with Mjg.
} 
6 New Order and Dayak marginalization (1966-1998)

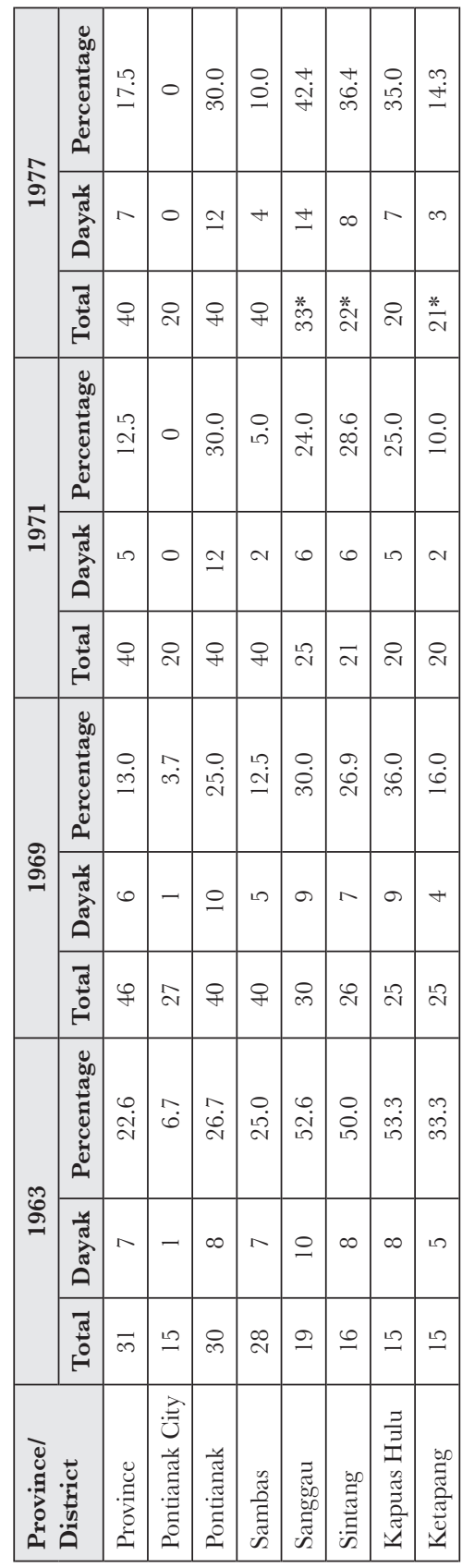

$\frac{\pi}{\tilde{0}}$

$\ddot{*} \stackrel{\circ}{\circ}$

เี

퐁

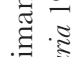

$\dot{v} \cdot \vec{n}$

施

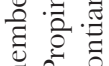

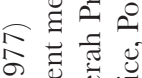

के हृ :

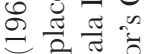

空过造

글

苍司

छहै है

约

总

党: :

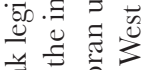

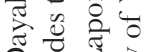

คิ

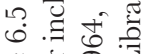

$\because$ 岀

तै है $\ddot{\Xi}$

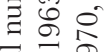

그

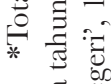

:

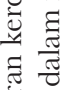

竞

$\ddot{0}$
$ٍ$
0
0

173 
win. ${ }^{49}$ Only a few of them appeared in the Golkar candidate lists because the majority still supported PK and IPKI. Some top Dayak leaders of the former Partindo publicly announced their switch to Golkar only on 17 April 1971, too late for them to be included in the Golkar lists, because the DCT was fixed days before the switch was announced. ${ }^{50}$ Only those who had joined Golkar earlier were included in the DCT. ${ }^{51}$ As a result, their number in the Golkar DCT was very low at the provincial level. There were 58 candidates in the provincial Golkar DCT, but only four were Dayaks. None of the Dayak candidates was considered well-known. They were placed outside the first sixteen candidates of the provincial Golkar DCT ${ }^{52}$ to show their less important status in Golkar. None of them had signed the declaration in April 1971. In the interior districts, more Dayaks were placed on the Golkar candidate list, although their numbers were still far from proportional vis-à-vis their percentage of the population. In Sanggau district, for example, of the 36 candidates on the provisional list, only twelve were Dayaks. Of these twelve Dayaks, only four were in the electable top ten positions.

Probably realizing the poor and inappropriate representation of Dayaks among its legislators, Golkar appointed (not through the election mechanism) several Dayaks to membership in of the DPRD. ${ }^{53}$ At the provincial DPRD, Golkar added G.P. Djaoeng, in Pontianak district Rachmad Sahuddin and Sadjali Usman, in Sanggau Willem Amat, and in Kapuas Hulu Aloysius Kahendi. ${ }^{54}$ In the end Golkar had only three

49 Election statistics from 1971 to 1987 show Golkar gaining about 69 per cent of the vote in each election at provincial level. Golkar performance in interior districts (Sanggau, Sintang, Kapuas Hulu, and Ketapang) was very high, about 81 per cent of total votes in the districts. It obtained fewer votes in coastal districts, about 60 per cent.

$5^{\circ} \quad$ The DCT was signed in Jakarta on 20 April 1971. All nominations in the DCT must have been fixed at the provincial level at least a few weeks before the official signing.

$5^{1} \quad$ Some such individuals were Lengson Angking and F.X. Matjok for the Sintang district, and Amin Amer and Aspan Tiong for the Pontianak district and Petrus Anjioe Nyangun, Anggang Kabay, Heronimus Godang, and Akien Alief for the provincial level ('Himpunan kegiatan/aktivitas DPRD Propinsi Kalimantan Barat: Periode tahun 1971/1972 s/d 1972/1973', 1973, in: Library of West Kalimantan Governor's Office, Pontianak).

$5^{2}$ 'Himpunan kegiatan/aktivitas DPRD Propinsi Kalimantan Barat: Periode tahun 1971/1972 s/d 1972/1973', 1973, in: Library of West Kalimantan Governor's Office, Pontianak.

53 According to regulation PP 2/1970 there were two types of appointed members to the regional DPRD: members with a military background and those with none (Article 10). In the case of candidates from non-military background, the final decision would be made by the interior minister based on recommendation by the regional Sekber Golkar (Article 11).

54 Interestingly, backdoor negotiation resulted in the appointment of Rachmad Sahuddin, even though he was officially listed representing IPKI at the election. At least four of the five Dayaks appointed as additional Golkar Dayak legislators were civilian and former members of Partindo. 
Dayaks among its 21 members of the provincial DPRD, one legislator in Sambas district and none in the Pontianak municipality. In interior districts, such as Sanggau, Sintang, Kapuas Hulu and Ketapang, less than a third of Golkar DPRD members were Dayaks.

After the 1977 election, Dayak numbers in the provincial DPRD and in some district DPRD started to rise, although they had not reached the 1958 level. Their number in the provincial DPRD was generally more than 25 per cent. Similar trends also appeared in the interior districts. One reason for the growth was the increase in the number of Dayaks who had switched to Golkar to be eligible for better political opportunities. The switch was also encouraged by the loosening emotional ties between the Dayak and the 'Dayak' political parties (such as PK and IPKI) due to a series of merges. This is particularly true after PK and IPKI, together with other non-Dayak political parties, were merged into the PDI in 1973. As a result of the merging of five nationalist and Christian

\begin{tabular}{|c|c|c|c|c|c|c|c|c|}
\hline \multirow{2}{*}{$\begin{array}{l}\text { National/ } \\
\text { Provincial/ } \\
\text { District } \\
\text { level }\end{array}$} & \multicolumn{3}{|c|}{ Legislators } & \multirow{2}{*}{$\begin{array}{c}\text { Total } \\
\text { Dayaks } \\
\text { (percentage) }\end{array}$} & \multicolumn{4}{|c|}{ Legislators by political party } \\
\hline & Total & Elected & Appointed & & PK & Golkar & IPKI & Others \\
\hline $\begin{array}{l}\text { National } \\
\text { DPR }\end{array}$ & & & & & 1 & $5(1)$ & 0 & \\
\hline Provincial & 40 & $32(5)$ & $8(1)$ & 15.0 & 2 & $21(3)$ & 2 & 7 \\
\hline $\begin{array}{l}\text { Pontianak } \\
\text { City }\end{array}$ & 20 & 16 & 4 & 0.0 & 0 & 10 & 0 & 6 \\
\hline Pontianak & 40 & $32(12)$ & $8(2)$ & 30.0 & 3 & $17(6)$ & $2(2)$ & $10(1)$ \\
\hline Sambas & 40 & $32(2)$ & 8 & 5.0 & 1 & $19(1)$ & $3(1)$ & 9 \\
\hline Sanggau & 25 & $20(6)$ & $5(1)$ & 24.0 & 3 & $13(3)$ & 0 & 4 \\
\hline Sintang & 21 & $17(6)$ & 4 & 28.6 & 1 & $14(5)$ & 0 & 2 \\
\hline $\begin{array}{l}\text { Kapuas } \\
\text { Hulu }\end{array}$ & 20 & $16(5)$ & $4(1)$ & 25.0 & 1 & $11(3)$ & $1(1)$ & 3 \\
\hline Ketapang & 20 & $16(2)$ & 4 & 10.0 & 0 & $13(2)$ & 0 & 3 \\
\hline
\end{tabular}

Table 6.6 Number of PK, Golkar and IPKI seats from West Kalimantan after the 1971 election

Note: PK shows all Dayaks; for Golkar and IPKI Dayaks are in parentheses.

Source: Various sources, Varia 1971/19-20. 
political parties, PDI could exert less emotional influence on the Dayaks than the PK and IPKI (or Partindo) had done in the past. ${ }^{55}$

The switch was quite obvious in the 1977 election when many Dayaks who had run for PK and IPKI in the 1971 election then became candidates for Golkar. Oevaang Oeray joined Golkar and campaigned for the party in 1977 (Akcaya, March-April 1977; Davidson 2008:108). The switch was also reflected in the Golkar candidate lists in the 1977 election, and later in the actual number of Dayaks elected into the DPRD. Three of the first four Golkar candidates for the national DPR were Dayaks: Oevaang Oeray in first place, Aloysius Aloy second, and Mozes Nyawath Elmoswath fourth. At the provincial level, Golkar listed two among its first ten candidates. In interior districts such as Sanggau, Sintang, and Kapuas Hulu, about half of the first ten Golkar candidates were Dayaks.

Larger Dayak representation in the DPRD from the end of 1970s, unfortunately, could not guarantee that their interests would be looked after. On the contrary, as already noted, Dayak interests remained largely neglected throughout the New Order. The members of DPRD, like anywhere else in Indonesia, were a mere rubber stamp for the executive. ${ }^{56}$ Furthermore, under the repressive regime, majority Dayak legislators chose not to raise ethnic concerns, a taboo subject under the New Order regime. ${ }^{57}$

\section{DAYAK VOICES IN DISTRICT HEAD ELECTIONS}

Although ethnic politics was considered taboo under the New Order regime, Dayak political voices were not completely muted. In August 1971, a month after the general election, a newspaper sympathetic to the Dayaks and with ties to the Catholic Church criticized the government for not bringing more Dayaks into the parliament. The author of the article believed that Dayaks and Chinese had contributed significantly, voluntarily or involuntarily, to the Golkar victory. He suggested that Golkar should have twelve Dayak members in the provincial DPRD.

\footnotetext{
55 Five political parties - PK, IPKI, PNI, Parkindo, and Murba - merged into PDI in 1973.

$5^{6}$ See for example an interview with the former head of Sanggau DPRD in Dayak leaders' memories (2005:10)

57 It was not surprising that after Reformasi some Dayak activists often referred to these Dayak legislators as tools of the New Order regime and refused to cooperate with them.
} 
The author, who was a military priest, was put under house arrest for almost a month as a result of the publication (Doera 2003:301-3). This was followed by another more covert statement two months later by G.P. Djaoeng, a former Dayak district head of Sintang, who was appointed a Golkar legislator to the provincial DPRD. He raised the issue of how unfair practices had sidelined segments of the society (meaning the Dayaks) and demanded fairer policies in recruiting them to the civil service. ${ }^{58}$

In a 1981 case, some Dayak leaders from Golkar in Sanggau demanded the appointment of more Dayaks to important positions in the executive and legislature. According to a report on the issue, a group of eleven Dayak politicians warned the government that if those demands were not met, Golkar would lose the 1982 election in Sanggau. The report accused them of trying to play on ethnic sentiments and urged the government to punish them. ${ }^{59}$ The governor claimed in a confidential report in 1982 that there were people who wanted to use the ethnic issue to affect the selection of parliamentary candidates. ${ }^{60}$ Very likely the governor was referring to the same event.

In June 1993, several months after a national seminar on Dayaks held by the Institut Dayakologi, three Dayak politicians wrote a letter to the governor and copied it to the president and all related institutions in Jakarta and West Kalimantan. In the letter, dated 21 June, G.P. Djaoeng, Rachmad Sahuddin and A.R. Mecer ${ }^{61}$ claimed that Dayaks had been marginalized by the government (in this case, Golkar) despite their contribution to Golkar's election wins. They demanded at least three district head positions for Dayaks, and asked that they be given more opportunities to work in government offices and chances for promotion. ${ }^{62}$ It seemed that the government was finally prepared to address the ethnic imbalance

\footnotetext{
${ }_{5}^{8} \quad$ Varia 1971/19-20:6-7. The statement did not specifically mention Dayaks, but it quite explicitly addressed the lack of political opportunities they had.

59 'Laporan khusus: Kelompok 11 di Sanggau', 1981, in: Private collection, Sanggau.

6o 'Laporan situasi keamanan, ketertiban dan ketentraman masyarakat dalam wilayah Kalimantan Barat'. 1982, p. 4, in: Library of West Kalimantan Governor's Office, Pontianak.

${ }_{61}$ Djaoeng was the first Dayak district head in Sintang. He later represented Golkar in the provincial DPRD and served as an advisor to the party. Sahuddin was the leader of Pontianak IPKI, but later joined Golkar. He had served as a Golkar legislator for Pontianak district and later for several terms in the provincial DPRD. He was one of the party deputy chairmen until 1989. A.R. Mecer was a member of Golkar and head of the expanding Dayak NGO, Pancur Kasih.

62 G.P. Djaoeng, Rachmad Sahuddin and A.R. Mecer, 'Pernyataan aspirasi masyarakat Dayak Kalimantan Barat dalam menyongsong PJPT II', 1993, in: Private collection, Pontianak.
} 
to avoid more serious problems. Its attempts to install Dayak district heads in Sintang and Kapuas Hulu in 1994 and 1995 illustrates this. ${ }^{63}$

\section{SINTANG DISTRICT HEAD ELECTION 1994}

District head elections under the New Order held almost no surprises. The identity of the next district head had usually been decided jointly by the governor, the local military leader, and the local Golkar leader in consultation with the central government several months before each election. Golkar proposed the final list of three candidates after deliberation with the other two smaller political parties, which would usually concur with the decision. The other two candidates were only accompanying candidates to make the election appear democratic and would not normally pose threats to the regime's candidate. The election process would go as planned with the regime's favourite obtaining the majority of the votes and being sworn in as the next district head. A comparable election process was also administered for the governor's seat (Malley 1999:85-7).

In the early 1990s a few election surprises did occur, when the government's favoured candidate was defeated. The causes were either that the members of the DPRD resisted the pressure to vote for the regime's candidate or because of a strong local demand that the government appoint another popular candidate. In December 1993, the election for the Central Kalimantan governorship reached deadlock after the government's candidate obtained 24 votes, three votes more than the Dayak candidate. Local people demanded that the central government appoint the Dayak candidate. Eventually, in order to prevent further complication without showing that it bowed to popular demand, the regime asked both candidates to resign, and appointed a third person as a caretaker (Malley 1999:90-3). Media Indonesia (8-3-1994) listed similar cases in the district head elections. In the Kutai district head election in March 1994, more than half of the members of DPRD refused to participate in the voting because their local candidate did not make the final short-list (Media Indonesia, 8-3-1994). There were other anomalies in Deli Serdang (North Sumatra), East Sumba and East Flores (East Nusa Tenggara), and Viqueque (East Timor) almost at the same time. In West Kalimantan during the election in Sintang in 1994, the unexpected happened when the governor's candidate, L.H. Kadir, was defeated.

63 Davidson (2002:268-9) was the first to highlight the importance of these two elections in Dayak politics, although he did not elaborate on the intensity of the inter-ethnic political feuds. 
L.H. Kadir was one of the two highest-ranking Dayak bureaucrats in the provincial office at the time. ${ }^{64}$ From 1982 to 1998, he had served as head of several bureaus in the provincial office. He began his career as the first Dayak to enrol at the government Civil Service Institute, the $\mathrm{KDC}$, and the first to enrol at the APDN. Before he was nominated as district candidate, he had headed a few bureaus and departments within the provincial bureaucracy (KR 1999/43:33). Career-wise, Kadir had held the highest possible position attainable by Dayaks during the New Order period because no Dayaks had held higher positions, such as assistant and deputy governor. Kadir was the governor's favoured candidate in the Sintang district head election in 1994 (Abdulsalam 1997:157). The governor showed his support for Kadir through a series of consultations with members of the district DPRD. ${ }^{65}$ District and provincial Golkar offices also officially nominated him (Fayakarta, 8-4-1994). The other accompanying candidates, Abdillah Kamarullah and Abdul Hadi Karsoem, were Malay bureaucrats in Sintang district. Kadir should not have had any difficulties winning the race because Golkar and military factions, which had supported his candidacy, occupied almost 80 per cent of the seats in the DPRD. However, the result of the vote in February 1994 turned out to be different from the usual scenario. Kamarullah won the election with 21 votes, while Kadir only gained 16 votes and Karsoem just one. ${ }^{66}$ Unfortunately for the Dayaks, the regime did not try to reverse the result, but instead, immediately applauded the election as a democratic and fair process conducted without interference (Kompas, 12-2 and 2-3-1994; Akcaya, 1-3 and 3-3-1994). It was quite unusual for the regime to celebrate the defeat of its own candidate.

For many Dayaks, Kadir's failure heightened their conviction that there had been concerted efforts to marginalize them in the bureaucracy, including tacit approvals from the central government. Tammar Abdulsalam, a Malay deputy governor in region II, who was given the responsibility of overseeing the election, was believed to have abetted the plot to sway votes from Kadir to Kamarullah. ${ }^{67}$ The Dayak head of the Golkar faction calculated that the defeat was caused by the defection

\footnotetext{
$6_{4}$ The other was Sotorman Benteng, a former BPH member in the 1960s.

${ }_{5} \quad$ Interview with Mlg.

66 Kadir himself was not present during the election. One source mentions that Kadir was not interested in the position because of family considerations. His lack of interest might have encouraged the manoeuvre not to elect him (interview with $\mathrm{Kdr}$ ).

${ }_{67}$ Various interviews; Abdulsalam 1997.
} 
of almost half the Golkar members. He was also convinced that the defectors were Muslims and non-Dayaks. ${ }^{68}$ Offensive slogans aimed at Dayaks during the election (Davidson 2008:231) further supported this ethnic explanation of Kadir's failure. ${ }^{69}$ On the other hand, the Malays saw Kamarullah's victory as a fair result because two previous district heads, Daniel Toding (Torajanese) and Bonar Sianturi (Batak), had been Christians. The Malays were very proud because the members of the DPRD had followed their heart and chosen a popular candidate rather than simply supporting the pre-determined government candidate.

The Dayak elite tried to repeal the result by sending delegations to Jakarta to ask for justice (Kompas, 1-3-1994). Demonstrations were also staged in both Sintang and Pontianak (Abdulsalam 1997:161-2). Some of their politicians even threatened to quit Golkar if Kadir was not installed as the district head (Akcaya, 1-3-1994; Kompas, 2-3-1994). The provincial Golkar secretariat, which had shown its approval of the election result, did not escape the protests. On one occasion, chairman of the provincial Golkar, Soemardji, was forced to issue a statement that the organization would sack disloyal members of the Sintang DPRD who failed to follow the party line. He even urged the president or interior minister to use his prerogative to elect Kadir. The Golkar headquarters responded by sending a delegation to investigate the matter (Akcaya, 2-31994). ${ }^{70}$ Unfortunately, the central government signalled that it would not reverse the election decision (Akcaya, 3-3, 23-3-1994).

After some intentional delays to allow tensions to dissipate, Kamarullah was sworn in with tight security as Sintang district head on 5 April 1994 (Akcaya, 6-4-1994; Davidson 2008:1 16). The inauguration inside the building was tense from the beginning with the heads of Golkar and PDI factions in the DPRD, both of whom were Dayaks, trying to obstruct the inauguration process. In Sengah Temila, about two hundred fifty kilometres from Sintang, hundreds of Dayaks vented their anger by blocking the main road connecting Pontianak and Sintang, waylaying and damaging official cars (Davidson 2008:116; Abdulsalam 1997:163). G.P. Djaoeng and several Dayak leaders who attended the inauguration

\footnotetext{
68 Interview with Mlg.

69 Davidson (2002:268) notes that following Kadir's defeat, leaflets were distributed claiming that during the vote count people shouted 'Dayaks are infidels'.

$7^{\circ}$ In the end, only three members of Golkar were pressured to resign from the DPRD: H. Mesir, Zulkarnaen, and Zulaeda (interview with Mlg).
} 
warned the government that denying Dayak interests would only push them to even more extreme reactions (Fayakarta, 8-4-1994).

Although the Dayak protests and lobbying effort failed, the episode sent ripples through Dayak politics for years into the future. It brought to the surface the issue of marginalization and Dayak-Malay political rivalries and set a precedent for overtly ethnic politics in the next district head elections. The victory of a non-government-backed candidate - in this case a Malay over a Dayak - showed that the authoritarian regime could relent. The opportunity came a year later during the district head election in the Kapuas Hulu.

\section{KAPUAS HULU DISTRICT HEAD ELECTION 1995}

The election of the district head in Kapuas Hulu in 1995 can be viewed as a continuation of the unfinished saga of the election in Sintang the previous year. In order to assuage Dayaks' anger, the governor reserved this post for a Dayak (Davidson 2008:115). The governor's choice was Jacobus Layang, a middle-ranked bureaucrat in the governor's office, who had a good relationship with the military. ${ }^{71}$ To boost his popularity, Layang initiated the formation of the provincial Dayak Customary Board (Majelis Adat Dayak, MAD) on 12 August 1994 and successfully campaigned to become its chairman (KR 2003/89; Davidson 2008:232). ${ }^{72}$

The governor's determination to appoint a Dayak district head was demonstrated by several political manoeuvres. He disregarded some Dayaks' opinion that the governor should appoint an able Malay bureaucrat, Setiman Sudin, as district head instead of the more junior Jacobus Layang. ${ }^{73}$ The governor also took steps to prevent a repeat of the Dayaks' failure during election in Sintang. Tammar Abdulsalam, who was responsible for the elections in Sintang and Kapuas Hulu, was temporarily relieved from duty. He was partly blamed for failing to deliver Kadir as Sintang district head. The regime believed that his ardent

71 The governor did not choose the other more senior Dayaks in the bureaucracy such as Sotorman Benteng and L.H. Kadir. One inside source said that the governor regarded Benteng as weak, and could not back Kadir after he had failed to win in the election in Sintang the previous year (interview with Awn).

$7^{2}$ Layang himself had credentials in Dayak customary law (hukum adat) as indicated by his articles and research in this field. He was the author of a book on Dayak rebellions against the Japanese (Layang 1981) and of several research articles on Dayak customary land and laws published by Universitas Tanjungpura.

73 Interview with Kls. 
Islamic beliefs could endanger the nomination of the Catholic Layang. ${ }^{74}$ Replacing him was the incumbent district head of Kapuas Hulu, A.M. Djapari, who was known as a close confidant of Governor Aspar Aswin. To eliminate ethnic complications in the election and to ensure that the position would go to a Dayak, the interior minister was advised to exclude both Malay candidates, Abang Ramli and Rusny Usha, from the final list. As the result, the remaining three final candidates were all Dayaks: Jacobus Frans Layang, S.S. Sonan, and Stephanus Kupon (Akcaya, 18-3-1995). Finally, a senior Dayak politician, Iman Kalis, was dispatched as the governor's envoy to Kapuas Hulu prior to the election to ensure the victory of Layang. ${ }^{75}$

In the initial selection period, the Malay candidates, who realized that the post would go to a Dayak, claimed that they too were Dayaks (Abdulsalam 1997:165). When all Malay candidates were finally dropped from the lists, they manoeuvred to elect the best Dayak district head for the Malays' interests. They were scheming to elect Stephanus Kupon, who was known to be quite ill at that time. Their calculation was that if Kupon won the election he would not be serving in his position for long because of his poor health. ${ }^{76}$ If that happened, a Malay deputy district head would take over his position. ${ }^{77}$ In order to succeed, the schemers held a meeting one day before the election and suggested a narrow win for Layang. With this strategy Kupon could win the election with only a small swing in the voting, and the schemers could avoid being blamed for insubordination, because in an election small vote swings are possible. To this end, they also encouraged sub-ethnic divisions among the Dayak members of parliament. Sensing the manoeuvres, Iman Kalis, the governor's envoy, objected to the marginal winning strategy advanced by the Malay legislature during that meeting. He insisted Layang be given a decisive win with 18 votes, while Kupon should be left with only one. ${ }^{78} \mathrm{He}$ also worked behind the scenes to unify the Dayak vote behind Layang. Even after these efforts Layang still won by only a narrow margin of three votes. Without Kalis's persistence, Kupon, who was favoured by

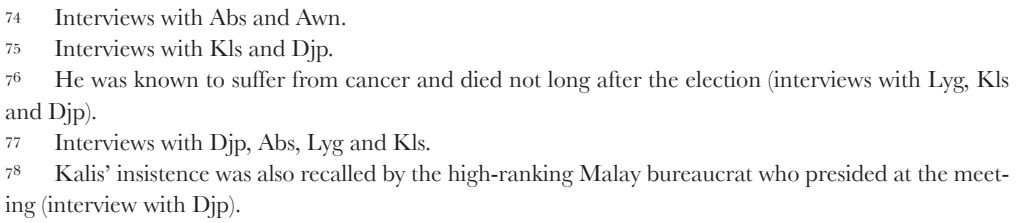


the Malays, would have won the election. Layang was elected as the first Dayak district head in the New Order.

In sum, during the New Order Dayaks' access to the bureaucracy was limited, even in districts where Dayaks were the majority population. They were also barred from occupying strategic positions in the executive, at least until 1995. Their share in the legislatures since 1977 had gradually improved although they had never achieved a majority in the council. Unfortunately, their growing share in the legislative branch was without much effect because the New Order DPRD was known to be subservient and subordinate to the executive. This experience of marginalization was not limited to political access, but also in economic and cultural aspects, as the following will discuss.

\section{ECONOMIC MARGINALIZATION}

The New Order brought economic stability and prosperity to many Indonesians. Before the crisis at the end of $1990 \mathrm{~s}$, general indicators had shown a significant increase in income level, life expectancy, and educational attainment. However, it was widely acknowledged that development had not been equitable, and many peripheral regions, particularly those in the Eastern part of the country, had enjoyed far fewer fruits of development. ${ }^{79}$ West Kalimantan was one such province having a lower standard of living despite its abundant natural resources. This section examines how uneven development has affected Dayaks by looking at the influence of logging and plantation activities and transmigration projects on rural Dayaks and discusses opportunities open to Dayaks in urban areas.

\section{LOGGING AND PLANTATION ACTIVITIES AND LOCAL DEVELOPMENT}

Kalimantan forests have been exploited since the late 1960s. With the Forestry Act of 1967 the government started to grant timber harvesting rights to many logging concessionaries $(\mathrm{HPH})$. The export of unprocessed logs rose sharply in the 1970 s and became an important source

79 Akita and Alisjahbana 2002; Akita and Lukman 1995; Soenandar 2005; Garcia and Soelistianingsih 1998; Sjafrizal 1997. 
of foreign exchange. Since the mid-1980s, because of the need for industrial wood, the government introduced timber plantations (HTI) especially in Sumatra and Kalimantan. ${ }^{80}$ As a result, the country's forest cover depleted from 93 per cent in 1950 to 75 per cent in 1985, and 60 per cent in 1997. West Kalimantan endured a similar deforestation trend with forest cover falling from 66.5 per cent prior to 1968 to 46.1 per cent in 1997 (FWI/GFW 2002:8, 12, 14).

Logging operations contributed most to West Kalimantan's forest loss. Prior to 1968, the province's 'production forest', an area where large-scale logging activities could take place, was the smallest among the Kalimantan provinces. It only designated 0.4 per cent of its total forest area of almost 10 million hectares as production forest. At the same time Central Kalimantan set aside designated 1.2 per cent, East Kalimantan 7.4 per cent, and South Kalimantan 18.8 per cent. By 1970, West Kalimantan had caught up with the other Kalimantan provinces, with the proportion of production forest soaring to 37 per cent of the total forest areas in the province. In 1997 the share of production forest had climbed to 56.9 per cent. ${ }^{81}$ Added to further deforestation was the slow rate of replanting of trees (in some cases even the complete failure to replant) in logged areas. In 2002 almost half of the logged areas in the province were left abandoned after timbers were secured (Informasi kehutanan 2002).

The activities of industrial timber (HTI) and oil palm plantations caused deforestation too. By 2002, the total forest allocated for HTI was about 1.1 million hectare, about 21 per cent of the province's production forest, or about 11.3 per cent of its total forest. In 2002 the area occupied by oil palm estate crops was about 6.7 per cent of total areas occupied by forests. ${ }^{82}$ Most of the HTI sites were intentionally located in thick forest

8o Triwibowo and Haryanto 2001:3, 7; FWI/GFW 2002:24, 36; Okamoto 1999:3-4

$81 \quad$ For the statistics, see 'Laporan umum Gubernur Kepala Daerah Propinsi Kalimantan Barat kepada menteri dalam negeri', 1970, in: Library of West Kalimantan Governor's Office, Pontianak; Statistik kehutanan 1968; Informasi kehutanan 2002. A local source even claimed that 94 per cent forest in the district such as Ketapang was allocated to logging activities (Andasputra 1999:1).

$8_{2}$ The rapid growth of plantations, particularly palm oil plantations, in the province could be tied with the government's enthusiastic support for plantations. For example, since 1986 every new oil palm estate has been required to be linked to transmigration, which itself helps the growth of the plantation program. Another contributor was the accessible road to inland regions. The road construction to northern and northeastern of the province started in the 1970s with the help of the Australian government (for aid, see Investment opportunity 1982:17). One aim of the road construction was to develop the interior areas and most importantly to enable rapid mobilization of security forces if there were security threats in the region. These areas were the domain of the Communist rebels at the end of the 1960s. 
areas partly because of the potential revenue from clear-cutting, i.e. selling the timber. ${ }^{83}$ Generally, because the main objective was to secure the marketable timber, replanting of the cleared areas for the HTI project was very slow. In West Kalimantan the planting rate was at 11 per cent of the total allocated HTI area, less than half of the national rate (FWI/ GFW 2002:38-9).

Traditional shifting cultivation and transmigration were not major contributors to deforestation, despite the common belief that this is so. Traditional shifting or 'slash-and-burn' cultivation, which the government blamed for forest depletion and devastating forest fires, had little impact on forest depletion compared to large-scale logging and plantation projects. According to J. Dick, traditional farmers were responsible for no more than 21 per cent of total forest loss (FWI/GFW 2002:47). Transmigration, too, contributed a small amount to forest loss. Up until 1998, seventeen transmigration sites had taken over 43,434 hectares, or less than one per cent of West Kalimantan forests (FWI/GFW 2002:50).

Most plantation and logging projects were located in rural and interior regions, which were thickly forested and sparsely inhabited. Table 6.7 shows that interior districts such as Sanggau, Ketapang, Sintang, and Landak had the largest areas under palm oil cultivation. The Dayaks are known to be the majority populations in these districts, and consequently would experience the effects of plantation and logging activities.

Logging and plantation operations could stimulate the local economy and improve standards of living. Setting up logging and plantation activities is usually accompanied by the construction of roads for transportation of the products. New roads open isolated regions and give more social and economic opportunities to the population. Health and education facilities were also often established in large plantations, particularly those linked to the transmigration program (known as PIR-Trans). Large logging companies were usually required to build social and health facilities for local populations. In short, these operations theoretically would open up previously isolated areas, attract labourers and stimulate the local economy. However, negative effects soon arose from mismanagement and corruption of plantation companies and government officials.

Researchers have shown that plantation and logging operations lowered the living standards for many Dayaks (Alqadrie 2002b:23;

$8_{3}$ One study found that 72 per cent of the total area of seven HTI was forest (FWI/GFW 2002: $37,41)$. 


\begin{tabular}{|c|c|c|c|c|c|c|c|c|c|c|}
\hline 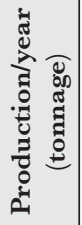 & $\frac{a}{a i}$ & $\begin{array}{l}\Delta \\
0 \\
\text { in }\end{array}$ & $\hat{6}$ & $\begin{array}{l}\hat{O} \\
\text { o }\end{array}$ & $\begin{array}{l}8 \\
0 \\
0\end{array}$ & $\begin{array}{l}\stackrel{\overrightarrow{ }}{ } \\
\text { जे }\end{array}$ & $\begin{array}{l}\tilde{v} \\
\tilde{v}\end{array}$ & 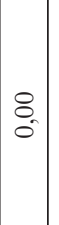 & 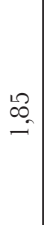 & $\vec{a}$ \\
\hline 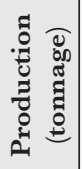 & $\begin{array}{l}\text { Dे } \\
\text { Dे } \\
i n\end{array}$ & $\begin{array}{c}\Omega \\
\hat{D} \\
\dot{0} \\
\dot{0}\end{array}$ & $\begin{array}{l}+0 \\
0 \\
0 \\
0 \\
0 \\
-1\end{array}$ & 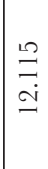 & 0 & 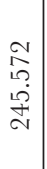 & $\begin{array}{l}\hat{0} \\
\dot{0} \\
\stackrel{R}{R}\end{array}$ & 0 & $\begin{array}{l}+ \\
\stackrel{0}{2} \\
\stackrel{2}{\longrightarrow}\end{array}$ & $\begin{array}{l}\stackrel{8}{0} \\
\stackrel{0}{n}\end{array}$ \\
\hline 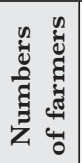 & 0 & 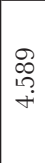 & $\frac{F}{\dot{m}}$ & \begin{tabular}{|l}
2 \\
0 \\
6 \\
-1
\end{tabular} & 0 & $\begin{array}{l}\exists \\
m \\
m \\
m\end{array}$ & 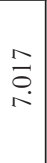 & $\stackrel{\vec{n}}{\rightarrow}$ & $\begin{array}{l}\bullet \\
\sigma \\
\dot{ \pm} \\
\dot{ \pm}\end{array}$ & $\begin{array}{l}\text { n } \\
\text { in } \\
\dot{8}\end{array}$ \\
\hline 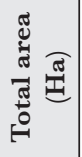 & $\begin{array}{l}\vec{\sigma} \\
\infty \\
\sim\end{array}$ & $\begin{array}{l}10 \\
\stackrel{n}{2} \\
\stackrel{2}{\alpha}\end{array}$ & $\begin{array}{l}\infty 0 \\
0 \\
0 \\
0 \\
-1\end{array}$ & $\begin{array}{l}\vec{\Upsilon} \\
\dot{O} \\
\sigma\end{array}$ & 0 & 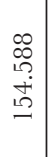 & $\begin{array}{l}\stackrel{g}{N} \\
\stackrel{9}{q}\end{array}$ & $\begin{array}{l}0 \\
\stackrel{2}{1} \\
00\end{array}$ & $\begin{array}{l}\stackrel{1}{\infty} \\
\infty \\
\infty \\
\infty \\
\infty\end{array}$ & $\begin{array}{l}\vec{\sigma} \\
\vec{\sigma} \\
\text { +े }\end{array}$ \\
\hline 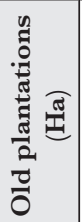 & 0 & \& & 0 & 0 & 0 & $\underset{\sim}{\stackrel{\sim}{~}}$ & 0 & $\underset{I}{\mathscr{I}}$ & 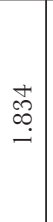 & $\begin{array}{l}\mathscr{Q} \\
\stackrel{\leftrightarrow}{v}\end{array}$ \\
\hline 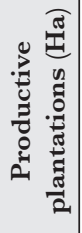 & $\begin{array}{l}\vec{\pi} \\
\hat{\alpha} \\
i\end{array}$ & \begin{tabular}{|l|}
0 \\
$\stackrel{0}{0}$ \\
$\dot{0}$
\end{tabular} & $\begin{array}{l}\hat{\theta} \\
0 \\
0 \\
0\end{array}$ & $\begin{array}{l}\hat{1} \\
0 \\
0 \\
ن\end{array}$ & 0 & $\begin{array}{l}0 \\
\mathscr{0} \\
\dot{0} \\
\dot{0}\end{array}$ & 号 & 0 & 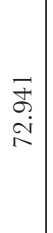 & $\begin{array}{l}\text { Iै } \\
\text { a } \\
\stackrel{\text { I }}{+} \\
\text { v }\end{array}$ \\
\hline 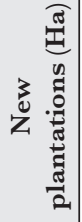 & $\begin{array}{l}\sigma \\
\text { oे } \\
\text { or }\end{array}$ & 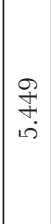 & $\begin{array}{l}\mathscr{S} \\
\stackrel{2}{1} \\
\dot{0}\end{array}$ & $\begin{array}{l}\vec{b} \\
\dot{\omega} \\
\text { d. }\end{array}$ & 0 & $\begin{array}{l}\text { Yे } \\
\text { f }\end{array}$ & $\begin{array}{l}\text { I } \\
\dot{I}\end{array}$ & $\infty$ & $\begin{array}{l}1 \\
\dot{c} \\
c \\
\stackrel{0}{-}\end{array}$ & $\begin{array}{l}\mathscr{\&} \\
\infty \\
\dot{8} \\
\stackrel{0}{0}\end{array}$ \\
\hline 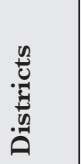 & 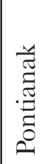 & 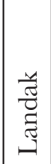 & 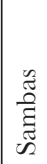 & 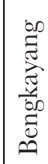 & 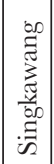 & 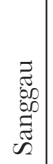 & 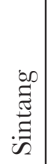 & 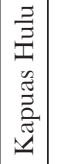 & 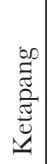 & 풍 \\
\hline
\end{tabular}


Mubyarto et al. 1991:23, 31). Large-scale logging and plantation operations reduced shifting cultivation areas so farmers were forced to recultivate the same plots of land more frequently. Frequent cultivation in shorter cycles left the soil with no time to recover; it therefore became less fertile and unlikely to yield good harvests. In the past when free forests

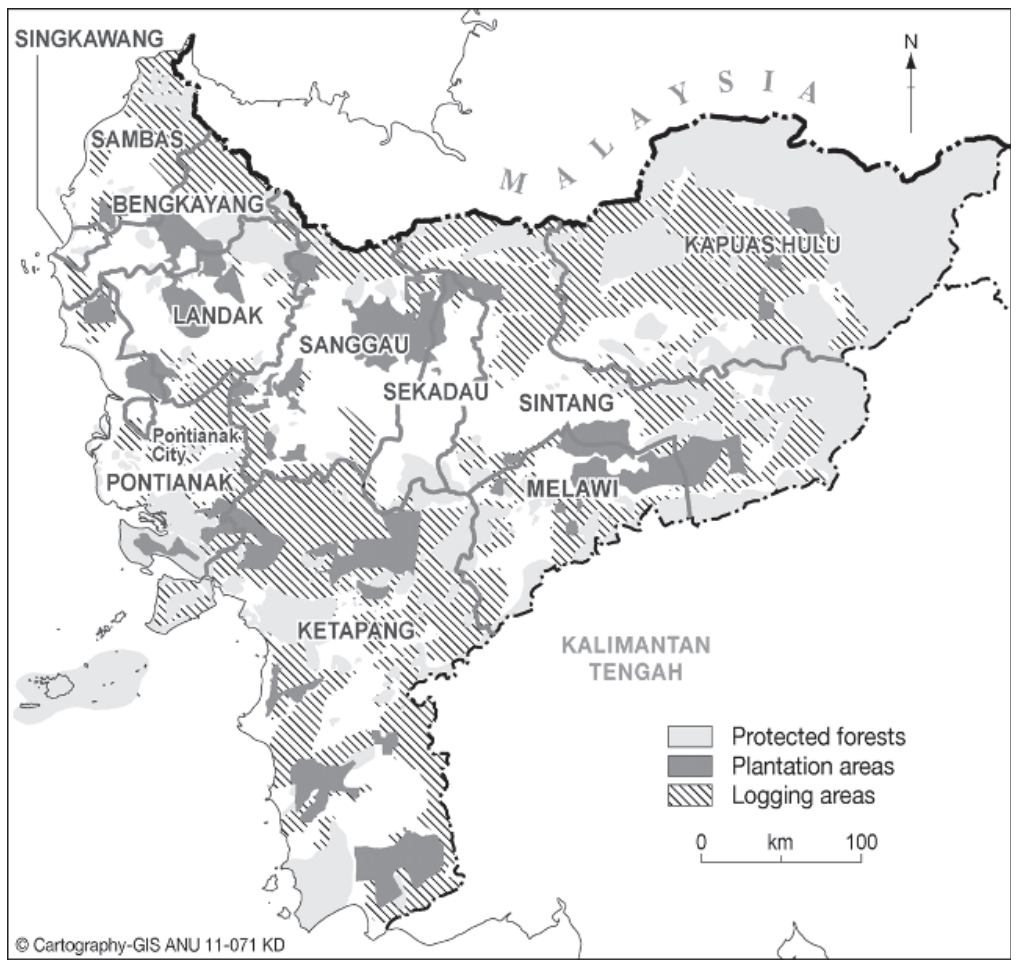

Figure 6.1 Logging and plantation areas (2002)

were still abundant, the land could be left fallow for up to twenty years so that it could recover its fertility before re-cultivation (Mubyarto et al. 1991:xxiii-iv). Dwindling forest areas also correlated with a decline in the population of wild animals - a source of protein for the villagers - as well as the reduction of forest produce, such as rubber, dry wood, fruits, honey, cinnamon, medicinal plants and rattan. In addition, Kalimantan Review reported cases in which locals had been barred from collecting 
produce from the forest after the plantations started to operate. Logging and plantation activities were also linked to reports of outbreaks of agricultural pests, increasing water and air pollution, and siltation which hampered river transportation (Florus and Petebang 1999:12).

Farmers who engaged in share-cropping plantation work did not experience any immediate improvement in their living conditions. Many had to wait six years after planting before they could reap the first harvest. In most cases, while awaiting the harvest, they were required to work at the plantation, usually for low wages. For eleven years after the first harvest, a third of their monthly income was deducted to cover the cost of running and maintaining their plots (Okamoto 1999:5; Florus and Petebang 1999:37). The whole process involved sophisticated calculations foreign to many farmers. Unfortunately, estate and plantation companies did not provide financial coaching. Researchers found some farmers were left with heavy debts resulting from a lack of financial planning (Okamoto 1999:5; Awang 1992:250-1; Djuweng 1996:86).

Plantations did not always provide better long-term employment opportunities for the local population. Some studies of the plantation system in West Kalimantan report that a majority of skilled employees in the plantation were not locals (Alqadrie 1990:173-4, 186-7; Awang 1992; Djuweng 1996:63). In Parindu Plantation (Sanggau), about 559 (77.2 per cent) of 724 employees were from outside West Kalimantan (Alqadrie 1990:269; Haryaningsih, Ngusmanto and Kusnadi 2000:84). Among all logging companies, only 1.7 per cent of the total number of employees were local, while the rest were outsiders (Djuweng 1996:xvi).

Apart from maintaining their plots, jobs available to local people on the plantation were as cheap contract labour. Finding alternative jobs for the locals was not easy because not many had the specific skills required for plantation operations. Also, some employers preferred to employ migrants rather than local people, who were considered poorly educated and unskilled, and were perceived as more difficult to deal with. In logging areas, with no alternative skills, less arable land and the need for quick cash, many Dayaks were eventually lured into logging activities, working independently or hired by the logging companies (Djuweng 1996:63).

The majority (70 percent) of respondents in Alqadrie's study (1990:182, 185) at the end of the 1980s disliked the plantation or logging activities in their region, and about half of them believed that such activ- 
ities did not benefit the local population. Anti-plantation protests started at the beginning of the 1980s, although they went unreported. Aware of the negative aspects of plantation activities, NGOs under Pancur Kasih and elements of the Catholic Church urged the local population to reject palm oil plantation development in their areas.

\section{TRANSMIGRATION AND INCREASED ECONOMIC COMPETITION}

There are four main migrant groups in West Kalimantan: the Bugis, Chinese, Javanese and Madurese. The significant influx of Bugis and Chinese had ceased before Indonesian independence, whereas the numbers of Javanese and Madurese began to increase significantly only after the 1970s. The majority of the Javanese came as participants in official transmigration schemes, while the majority of the Madurese are believed to have arrived as independent (swakarsa) migrants.

The first formal transmigration projects in West Kalimantan began in 1955 with only a few such projects before 1965, and the number of migrants over this period was small. Many of this first generation migration were still alive in the 1990s and constituted about 1.9 per cent of total migrant households. Transmigration grew rapidly during the New Order regime, reaching its peak in the 1980s. Most of West Kalimantan migrants went to the districts of Sintang (22.5 per cent), Ketapang (18.2 per cent), Pontianak (13.8 per cent), Sekadau (13.4 per cent), Bengkayang (11.1 per cent) and Sanggau (10.4 per cent).

In principle, transmigration is meant to benefit both migrants and locals or natives. Through transmigration, the government intended to balance the distribution of population and labour force, to utilize natural resources, to raise the standard of living, to support regional development and reduce inter-regional disparities. Transmigration could also foster nation-building and strengthen national defence and security (Fasbender and Erbe 1990:30-1). Ideally Dayaks and other local people who lived near transmigration settlements would benefit from the new roads and educational and health facilities brought into their areas by transmigration in their areas. Those who became local transmigrants (known also as APPDT) would also receive allowances from the government (KR 2004/106). Despite these good intentions, problems and tension related to transmigration is common because of cultural differences, land disputes, economic competition, and other issues (Otten 1986:144- 
84). The following section will focus on the effect of transmigration on the Dayaks.

\begin{tabular}{|l|c|c|}
\hline Periods & Numbers of households & Percentage of total \\
\hline $1950-1960 \mathrm{~s}$ & 1,551 & 1.9 \\
\hline $1970 \mathrm{~s}$ & 2,197 & 2.7 \\
\hline $1980 \mathrm{~s}$ & 47,932 & 59.5 \\
\hline $1990 \mathrm{~s}$ & 28,908 & 35.9 \\
\hline Total & 80,588 & \\
\hline
\end{tabular}

Table 6.8 Transmigration to West Kalimantan (1950s through 1990s)

Source: http://www.nakertrans.go.id/statistik_trans/DATA percent20UPT/

UPT percent20SERAH/prov_KALBAR1.php (accessed 9-10-2005).

In general, the natives of Sumatra, Kalimantan and Sulawesi did not welcome the Javanese and Balinese migrants, particularly if the migrants threatened to become a majority in the local region. ${ }^{84}$ This was very real possibility because a transmigration site usually accommodated several hundred migrant households and could overwhelm relatively small and scattered local populations in the interior. Many natives were sceptical of transmigration because the government supported the migrants but seemed to neglect equally poor locals. As a rule, the government provided sponsored migrants with housing, free land (two hectares or more), food supplies for up to eighteen months, and various resources for production, such as seed fertilizer, livestock, necessary tools and equipment (Fasbender and Erbe 1990:52-3). Migrants who participated in the plantation program (or PIR-Trans) from the 1980s also received plots of plantation land. ${ }^{85}$ Local people did not receive such government support, and as a result resentment and jealousy toward the migrants inevitably grew.

84 In the case of Irian Jaya, by the early 1980s over 250,000 transmigrants had been added to the province's population of only 750,000 . The regime had planned to bring in a further one million during the 1980s, which would reduce the native Papuans to a minority (Drake 1989:57, 132). This kind of population resettlement for political purposes was not uncommon in countries with many ethnic groups. $8_{5}$ From 1989 to 1995, there were 28,749 households participating in PIR-Trans (KR 2004/106). Local people were allowed to participate in the PIR-Trans projects; however, they had to repay an amount of debt similar to that of migrants. Locals were unhappy and argued that since they had given part of their land, they should not pay the same amount as migrants (Dove 1985a, 1986). 


\begin{tabular}{|c|l|c|c|c|c|c|}
\hline \multirow{2}{*}{ Number } & \multirow{2}{*}{ Location } & \multirow{2}{*}{$\begin{array}{c}\text { Established } \\
\text { since year }\end{array}$} & \multicolumn{2}{|c|}{ Transmigrant sites } & \multicolumn{2}{|c|}{$\begin{array}{c}\text { Transmigrant } \\
\text { households }\end{array}$} \\
\cline { 4 - 7 } & & & Numbers & $\begin{array}{c}\text { Percentage } \\
\text { of total }\end{array}$ & Number & $\begin{array}{c}\text { Percentage } \\
\text { of total }\end{array}$ \\
\hline 1 & Sambas & 1982 & 10 & 4.7 & 3,810 & 4.7 \\
\hline 2 & Bengkayang & 1980 & 19 & 8.9 & 8,961 & 11.1 \\
\hline 3 & Pontianak & 1955 & 27 & 12.7 & 11,098 & 13.8 \\
\hline 4 & Landak & 1982 & 1 & 0.5 & 100 & 0.1 \\
\hline 5 & Sanggau & 1980 & 21 & 9.9 & 8,408 & 10.4 \\
\hline 6 & Sekadau & 1982 & 27 & 12.7 & 10,778 & 13.4 \\
\hline 7 & Sintang & 1980 & 53 & 24.9 & 18,127 & 22.5 \\
\hline 8 & Melawi & 1980 & 5 & 2.3 & 2,250 & 2.8 \\
\hline 9 & Kapuas & 1984 & 8 & 3.8 & 2,421 & 3.0 \\
\hline 10 & Kulu & & & & & 14,635 \\
\hline Total & & 1983 & 42 & 19.7 & 80,588 & 100 \\
\hline
\end{tabular}

Table 6.9 Transmigration sites and households in West Kalimantan (1955-2000) Source: http://www.nakertrans.go.id/statistik_trans/DATA percent20UPT/ UPT percent20SERAH/prov_KALBAR1.php (accessed 25-3-2006)

The government tried to alleviate some of these problems by allowing some locals to be part of transmigration projects from the late $1970 \mathrm{~s}$ (regulation Keppres 1/1978). Local people who participated in the project would receive the same entitlements as the migrants. The number of such local migrants was nationally set at 10 per cent of the total site population, although in West Kalimantan the cap could reach 50 per cent, and even more than 81 per cent in some sites. ${ }^{86}$ Unfortunately, these measures did not solve the problem for all local migrants. Many left and went back to their original dwellings because they did not settle well into different lifestyles and cultures or they had exhausted governmentprovided resources (KR various issues; Otten 1986:164-6).

86 Fasbender 1990:54-5; Kepala Kantor Wilayah Departemen Transmigrasi dan Pemukiman Perambah Hutan Kalimantan Barat 1998:56. In a more recent example in 2004, the local population in Seberuang sub-district, Kapuas Hulu protested against the district government policy to open a new transmigration site where the local people would only get a 40 per cent allocation. The protest succeeded in pressuring the government to change the allocation to 50 per cent (KR 2004/110). 
Land disputes were another source of local resentment toward the migrants. In most cases, the regime appropriated land and handed it over to migrants without properly compensating the local landowners. One study found that the majority of local people in Sanggau Ledo (Bengkayang) in 1986 received no compensation when the government converted their land to a transmigration site (Djuweng 1996:93). In 1984, some Dayaks from Nobal (Sintang) complained to a local bishop and to the district head about the lack of financial compensation for their land which had been converted to transmigration sites (Roekaerts 1985:29). After locals objected strongly, a plantation in Parindu (Sanggau), which was originally designated for migrants, was returned to local ownership (Sapardi 1992:130). People were dissatisfied with the compensation although formal complaints were few or not well documented because of the authoritarian nature of the regime at that time.

Dayaks and some segments of other local populations also believed that the migrants had taken away their jobs, particularly jobs in lowpaid sectors, such as in mining and logging. When illegal mining riots broke out in Samalantan (Sambas) in March 1996, a majority of illegal gold miners (PETI) in West Kalimantan were outsiders. ${ }^{87}$ Fierce job competition was also a result of many migrants looking for jobs other than farming their allocated land (Usop 1992:103; Suhadak, Daliyo and Redmana 1977:20, 45). Common reasons for these migrants to venture out of farming were the need for immediate cash to support their families, the unsuitability of the land for farming, and difficulties in marketing produce due to poor infrastructure (Suhadak, Daliyo and Redmana 1977:20, 45). They were usually more flexible and less demanding but more aggressive in looking for jobs and therefore more likely to secure jobs than locals.

${ }_{7}$ Andasputra 1999:14-6. Similar phenomena could be found elsewhere. In the mining sites in Talangah village, Central Kalimantan, there were only 35 people, or around 0.9 per cent locals, working in the mines, while outsiders numbered around 5,000. Before the police sweep against the illegal mining, the number of outsiders reached 10,000 (Usop 1992:101). 


\begin{tabular}{|l|l|r|r|r|c|}
\hline \multicolumn{2}{|l|}{ Transmigration } & \multicolumn{3}{|c|}{$\begin{array}{c}\text { Number of transmigrant } \\
\text { households }\end{array}$} & $\begin{array}{c}\text { Percentage } \\
\text { of local }\end{array}$ \\
\hline \multirow{2}{*}{ Type } & \multicolumn{1}{|c|}{ Sites } & Local & Non-Local & Total & \\
\hline \multirow{4}{*}{ PIR-Sus } & Sensibo Baru & 1,112 & 256 & 1,368 & 81.3 \\
\cline { 2 - 6 } & Seluang & 305 & 828 & 1,133 & 26.9 \\
\cline { 2 - 6 } & Kinande & 190 & 169 & 359 & 52.9 \\
\cline { 2 - 6 } & Godang Damar & 391 & 205 & 596 & 65.6 \\
\cline { 2 - 6 } & Papan Tembawang & 201 & 289 & 490 & 41.0 \\
\cline { 2 - 6 } & Pombay & 213 & 223 & 436 & 48.9 \\
\hline \multirow{3}{*}{ TIR-Trans } & Jawai & 164 & 212 & 376 & 43.6 \\
\hline \multirow{3}{*}{\begin{tabular}{l} 
PIR-Trans \\
\cline { 2 - 6 }
\end{tabular}} & Sebuah Marong & 77 & 183 & 260 & 29.6 \\
\cline { 2 - 6 } & Sanung & 145 & 285 & 430 & 33.7 \\
\hline Food crop & Saparan III & 80 & 120 & 200 & 40.0 \\
\cline { 2 - 6 } & Paum & 26 & 103 & 129 & 20.2 \\
\hline Total & & 2,944 & 3,033 & 5,977 & 49.3 \\
\hline
\end{tabular}

Table 6.10 Transmigration household to Sambas district (1994-1995)

Source: Kabupaten Sambas 1996:50-3.

\section{LIMITED URBAN OPPORTUNITIES}

In developing countries like Indonesia, the establishment of important infrastructure and offices in the regions usually takes place first in the provincial capitals before being made available at the district capitals and in other cities or towns. These development priorities mean that those who live far from cities and towns will naturally be disadvantaged. Many Dayaks would have been disadvantaged as they lived in outlying areas - a demographic trend which has changed only slightly since colonial times. The population census in 1930 recorded very few Dayaks living in towns or cities: no Dayaks in Pemangkat and Sintang, only 42 in Singkawang (3.6 per cent), 40 in Pontianak (0.3 per cent), and 76 in Ketapang (2.3 per cent). Recent censuses show that Dayak populations in urban areas remain small. In the provincial capital, the proportion of Dayaks was only 2.9 per cent in 1980 and 3.3 per cent in the 2000 census. Even in districts with a significant Dayak population, their capitals usually had fewer Dayaks, except in Bengkayang. 


\begin{tabular}{|l|l|c|c|}
\hline \multirow{2}{*}{ Districts } & \multicolumn{2}{|c|}{ Percentage of Dayaks living in - } \\
\cline { 3 - 4 } \multicolumn{1}{|c|}{} & District capital & Total district \\
\hline \multirow{4}{*}{$\begin{array}{l}\text { With } \\
\text { significant } \\
\text { number of } \\
\text { Dayaks }\end{array}$} & Bengkayang & 75.2 & 52.4 \\
\cline { 2 - 4 } & Landak & 62.4 & 79 \\
\cline { 2 - 4 } & Sanggau & 34.4 & 61.2 \\
\cline { 2 - 4 } & Sekadau & 36 & 56.8 \\
\cline { 2 - 4 } & Sintang & 17.8 & 55.9 \\
\cline { 2 - 4 } & Melawi & 27.3 & 42.4 \\
\cline { 2 - 4 } & Kapuas Hulu & 35.4 & 39.7 \\
\cline { 2 - 4 } & Ketapang & 4.7 & 23.2 \\
\cline { 2 - 4 } & Average & 36.7 & 51.3 \\
\hline \multirow{4}{*}{ Others } & Pontianak City & 4.3 & 3.3 \\
\cline { 2 - 4 } & Sambas & 7.7 & 3.4 \\
\cline { 2 - 4 } & Singkawang & 3 & 7.5 \\
\cline { 2 - 4 } & Pontianak & 1.3 & 5.5 \\
\hline Average & & 4.1 & \\
\hline
\end{tabular}

Table 6.11 Dayaks in the district capitals (2000)

Source: Census 2000.

The number of Dayaks in the cities continued to be small because many of them could not afford the cost associated with urban migration. For those whose livelihood depended on farming in the outlying villages, moving into urban areas was not possible without jeopardizing their incomes. Once they left their farms they would lose their only source of funding. Finding a new job in the city for those who had no other skills but farming and lacked connections would be extremely difficult. It was no longer possible for them to move and farm the lands near the cities because there was no free land. Only Dayaks who worked as civil servants, were involved in business, or owned farms in nearby areas could live in the cities. A significant number of younger generation Dayaks who lived in the cities were actually students who were pursuing higher education. Upon graduation these students would need to find jobs in either the bureaucracy or the private sector to enable them to stay on. However, as mentioned previously, entry into these sectors was not easy because they had been under the domination of other ethnic groups. 
The bureaucracy was under the control of Malays, while business and private sectors were in the hands of the Chinese. These two ethnic groups, naturally, would protect the interests of their own members.

\section{CULTURAL MARGINALIZATION}

When the Dayak community leaders talked about the decline of their culture, they usually referred to the disappearance of longhouses, the declining role of traditional leaders, and diminished appreciation of their culture among the younger generation of Dayaks. This section will focus on factors outside the Dayak community's control, such as the introduction of contemporary world religions and government policies, as well as on the lack of cultural courage and pride among the Dayaks as the main contributors to cultural decline.

\section{ROLE OF MODERN RELIGION}

The introduction of foreign religions, especially Islam and Christianity, undermined Dayak cultural practices. As previously explained, in the past, after conversion to Islam the Dayaks usually abandoned their traditional practices and beliefs, and changed their identity to become Malays. Serious converts would often leave their community to settle in Malay communities because there were basic disagreements between Islam and many Dayak habits, such as drinking liquor and eating pork. For generations, Islam has changed the culture, habits, and identity of many Dayaks who became Muslims.

As with the introduction of Islam, Protestantism and Catholicism also contributed to the changing of Dayak culture and tradition. Unlike Islam and Protestantism which are usually rigid in their approach to the Dayak culture, Catholicism is generally more flexible and acceptable of Dayak culture. ${ }^{88}$ Generally, Dayaks who converted to Catholicism or Protestantism could continue to live in their community and practice their customs to certain extent. For example, magical chanting in

88 Within Christianity, Protestantism is perceived as more intolerant of animism and traditional religion than Catholicism. John Bamba claimed that Protestantism was the most incompatible religion with Dayak culture (Urano 2002:23). Having said that, there were also reports of strict Catholic priests in the past who demanded the new converts destroy all idols (Van Hulten 1992:133). 
traditional performances was replaced by Christian prayers, and sacrifices were changed to align with Christian practices and principles (King 1985:72-3; Maunati 2004:84-5). Research conducted on Dayak Ribun in Parindu (Sanggau) in 1980 also reached the same conclusion about the flexibility of Catholicism (Ahok et al. 1980:5). This flexibility enabled Catholicism to change as well as retain many elements of Dayak tradition. One Dayak scholar believes that Catholicism is adopting a more sophisticated and diplomatic approach to destroy Dayak culture (Urano 2002:23). The negative effects of Christianity on the eroding of local culture can be observed in other part of Kalimantan. In Central Kalimantan, a Dayak scholar, Fridolin Ukur, found that Christianity has resulted in Dayaks being uprooted from their culture. They did not have enough knowledge of their own culture, and the new generation was completely ignorant about it (Ukur 1971:242-3).

After the coming of the New Order, conversion to modern religions increased due to anti-Communist campaigns (Davidson 2008:105-6). A Protestant missionary who was working in the Bengkayang area observed that after the 1965 coup, and particularly after the 1967 conflict, both Christian and Muslim officers in the army encouraged the local Dayaks to convert (Humble 1982:45, 142). One ex-military priest recalled that a military commander backed the full-scale Islamization of the Dayaks, even by allowing new converts to continue their habit of consuming pork and alcohol. In some cases, Muslim preachers and informal leaders were forced to impose sanctions on those Dayaks who failed to convert to Islam (Doera 2003:166-74). Catholic leaders who were initially strict about orthodoxy and slow to convert Dayaks decided to make conversions much easier, for example by lifting the requirement to study the Bible before converting (Doera 2003:190-1). Church authorities even agreed to convert groups of Dayaks through the distribution of yellow cards (Davidson 2008:106). Conversion to Protestantism similarly accelerated. In Bengkayang the conversion rate increased dramatically from an average of 94 converts per year in the 1960s to 729 converts per year in the 1970s (Humble 1982:45, 142). Local press joined the effort by reporting news of conversion (Akcaya, 12-1, 28-11, 24-12-1979).

These efforts to convert the Dayaks were very successful. Although data on the religion of each ethnic group was not available in 1971, it was assumed that between 75 and 85 per cent of the 277,456 Catholic in the province in 1971 were Dayaks, and about the same percentage 
of the province's 84,372 Protestants. By 1980, the number of Catholic Dayaks had already reached 474,362; and in 2000 792,748. Numbers of Protestant Dayaks had increased from 167,096 in 1980 to 307,335 in 2000. Excluding the small percentage of recent Senganan, who were included in the Malay category for consistency in this book, almost 98 per cent of Dayaks were either Catholic or Protestant. The number of animist Dayaks, not surprisingly, fell precipitately during this period. According to the 1971 census, the number of people professing 'other religions' in West Kalimantan was 655,097, the majority (70-80 per cent) of whom were very likely Dayak animists. ${ }^{89}$ The number of Dayak animists had declined drastically to 116,665 by 1980 , and further reduced to 16,059 by 2000 .

\section{A HOMOGENIZING CULTURAL APPROACH}

After independence, Indonesia embarked on a nation-building process aimed at strengthening and cohesion the country's unity. One way was through the creation of national symbols to be shared by all Indonesians. In the early days of the nation, Indonesian leaders had decided on the national flag, anthem, language, and some other essential symbols. In more recent times batik (Javanese traditional dress) was elevated to the status of an official national dress.

These symbols were accompanied by the construction of national identity or values to bind diverse ethnic groups together. The rapid introduction of streets named after national heroes throughout Indonesia since the 1970s and 1980s was one example. In West Kalimantan, many Dayak villages which had local names were renamed with more common names which mostly followed the naming conventions of villages in Java. Some others were changed rather differently; for example, Iban villages were renamed Toba, Pulau Manak and Rantau Prapat by a Batak subdistrict head in the early 1980s. ${ }^{90}$

\footnotetext{
$8_{9}$ Other possible animists, the Chinese, were mostly registered as Confucianists in the 1971 census. According to the census there were 132,974 Confucianists in West Kalimantan. Their number dropped to 65,857 in the 1990 census. In the 1990 census, 173,609 or 60 per cent of West Kalimantan Chinese professed to be Buddhists as Confucianism had been deregistered as an official religion.

9o Toba, Pulau Manak and Rantau Prapat are names of places in North Sumatra, the origin of the Batak sub-district head. They later reverted to their original names after the Reform (Lumenta 2001:113; Soemardjan et al. 1992:Chapter VI).
} 
As part of nation building and in order to improve the standard of living and civilization, the government decided to transform the cultures of certain indigenous minorities which were thought primitive or too different from normal Indonesian citizens. These communities were usually known as masyarakat terasing or isolated communities. ${ }^{91}$ Sections of the Dayak community were also categorised as masyarakat terasing. The decision to include Dayaks as a primitive ethnic group was most likely influenced by the memory of their past practices of nomadic life, shifting cultivation, exotic culture, and headhunting. A publication in 1975 noted that West Kalimantan had 66 such a groups, all of whom were Dayaks, with total of 481,368 people (Laporan survey 1975:19-22). This number was almost half (42 per cent) of all Dayaks of West Kalimantan (based on the 1971 census). ${ }^{92}$ In the 1980s and 1990s, the number of isolated groups in West Kalimantan had decreased as a result of advancements in transportation and communication. Contributing to the decrease was the better understanding of Dayaks and an end to the blanket assumption that all Dayaks were backward and therefore isolated. A government source published in 1990 mentioned only four isolated, undoubtedly Dayak, ethnic groups in West Kalimantan: the Bekatan in Kapuas Hulu, Dayyu in Sambas, Baweng in Landak, and Miskin in Ketapang (Bale and Suprapti 1990:5). Ethnic stereotyping of Dayaks as backward and primitive did not disappear quickly. Although the practice of headhunting among the Dayaks had been largely stamped out by the beginning of the twentieth century, their association with headhunting continued as a result of conflicts in 1967, 1997 and 1999 in which headhunting occurred. Furthermore, many Dayaks still engage in traditional shifting cultivation, a practice government officials have blamed as the cause of recurring forest fires. ${ }^{93}$ This further fomented a false perception of Dayak culture as a whole.

One solution was to introduce migrants into the region through transmigration. Another was to resettle these isolated communities to somewhere with easy access for the government to monitor their 'prog-

${ }^{1} \quad$ Duncan 2004c; Li 1999. Other terms are also used for example suku terasing, masyarakat adat terpencil or more recently adopted komunitas adat terpencil which all have the inherent meaning of an isolated and backward group. See, for example, Duncan 2004b:90.

$9^{2}$ According to the 1971 census Dayaks were 41 per cent of the province's population. Since the total population was 2,019,924, the number of Dayaks was estimated at about 828,169.

93 The New Order government labelled this type of farmer as peladang liar (wild cultivator), a pejorative term, maybe as a way to discourage the practice. 
ress'. By 1994 the government had resettled 160,000 isolated people, and it estimated that over one million people still needed the attention of the government (Li 1999).

In the past, preservation of the longhouse in the traditional fashion was not difficult as they were an inherent part of Dayak life. The longhouses were built to protect Dayaks against headhunters, and they were centres of coordination of their economic activities, such as farming and hunting. They also were a venue for social and cultural activities, such as harvest festivities. The Malay sultanates and the Dutch colonials had no problems with the longhouses. In fact, the Dayak custom of living in longhouses made for easier tax collection and manpower mobilization in times of war. Dayaks who wanted to leave longhouses permanently were even required to pay cash fines and would often receive social punishment. ${ }^{94}$ Individual houses for the Dayaks were very rare before the turn of the twentieth century; however, the trend toward resettlement outside longhouses grew stronger after that.

Conversion to Islam was one of the first reasons. Serious Dayak converts moved out of the longhouses as their new faith was incompatible with longhouse living. The increase in Dayak population movements after independence also contributed to the trend toward abandonment of longhouses. Opportunities to pursue higher education and office work in urban areas led many Dayaks to leave the longhouses. The cessation of headhunting, a reason for Dayaks staying in longhouses, is another factor. ${ }^{95}$ New values brought by education and religion tended to question traditional leadership and customary practices, the very foundation of longhouses. These factors have made the function of longhouses less relevant (Coomans 1987:112-3; King 1985:73; Mudiyono 1994:2156). The influence of post-war Dayak leaders, such as Oevaang Oeray, convinced many to move into individual houses (Davidson 2002:97). However, despite the increasing preference for single-family homes after WWII, many Dayaks in rural areas still lived in them. The government

94 Until as recently as 1997 similar practices were still strictly observed in a longhouse in Melawi. The longhouse chief wished to take his family to live in the government houses near the road, but he could not afford to pay the fine. He would be fined if he left the community more than three days. He said that this rule can be abandoned only when the whole community agreed to shut down the longhouse (Sydney Morning Herald 8-2-1997).

95 Affecting the disappearance of headhunting was suppression by the European colonizers, the spread of modern religions, and peace meetings among the Dayaks (Alqadrie 1990:117). 
did little to actively try to eliminate longhouses during the first few decades after independence as it was not the government priority.

Under the New Order longhouses rapidly disappeared. The regime worried that communal living in longhouses could be a breeding ground for Communism. The Communist revival was a serious issue because of this region's previous experience with Communist rebellion and also as a consequence of the close relations of some Dayaks with Communist rebels. Besides political considerations, the government also thought that living in longhouses was unhealthy and dangerous because they were prone to fire. ${ }^{96}$ The head of the Dayak Customary Council of Sanggau district, Donatus Djaman, noted that at the end of the 1960s, the government instructed the Dayaks to destroy their longhouses. The military reportedly came to some Dayak villages and forced the residents to destroy their traditional houses. Some longhouses were burned down as a result (Dayak leaders' memories 2005:8-9).

There are no the statistics on the number of large and fully functioning longhouses in West Kalimantan. ${ }^{97}$ However, longhouses apparently had completely disappeared in coastal districts, except one in Saham village (Landak) which was preserved for tourism. Researchers have reported the existence of several longhouses in the interior, although their numbers are declining fast. In the early 1990s, Layang and Kayan reported three longhouses in Embaloh (Kapuas Hulu), and almost all the inhabitants of Batang Lupar (Kapuas Hulu) still lived in longhouses (Layang and Kanyan 1994:201). During her research in mid-1986, Helliwell (2001) found two longhouses in Gerai village (Ketapang).

The disappearance of longhouses, one of the pillars of Dayak culture, exacerbated the decline of Dayak culture. With their disappearance went the oral traditions, customs and performances, and sense of communal living among Dayaks (Drake 1982:49-52; Freeman 1970:125-6; Djuweng 1996:17, 124). The new communal centres, often built by government and attached to the village office, were not able to replace functions of the longhouses.

Through its patronizing cultural approach, the government also wanted to ensure higher levels of homogeneity in the society to facilitate

$9^{6}$ Dove 1985b; Roekaerts 1985; Djuweng 1996:17; Van Hulten 1992:xvi-xvii.

97 To give a perspective, the provincial government of East Kalimantan claimed in 1995 that it had about 92 longhouses, fifteen of which were still functioning or were in good condition (Maunati 2004:71). 
control. In 1979 the government introduced the Village Governance Law (UU 5/1979) that standardized all villages in the country. The regime abolished various local names for villages, and introduced a uniform term desa, the term for a village in Java. ${ }^{98}$ The name of the village head was also uniformly changed to kepala desa. The most significant aspect of this reform was village size, which now was to have at least 2,500 residents or 500 households (regulation Permendagri 4/1981). This requirement might be suitable for the more concentrated and overpopulated villages in Java and Bali, but not suitable for sparsely populated West Kalimantan. At the time of this mandated change, about 59 per cent of all villages in the province had 50 or fewer households, and about 23.2 per cent had between 51 and 100 households. To suit the condition of the province, the government lowered the requirement to 200 households per village ${ }^{99}$ but still many existing villages did not fit the criteria. As a result more than 80 per cent of 4,632 mostly Dayak villages were regrouped in the early 1980s. This forced village reorganization required many adjustments that in some cases resulted in tensions among the former village leaders as well as among the villagers. Village reorganization caused dissatisfaction among former village chiefs who had lost their leadership positions. Villagers also complained that they had to travel a long distance to see the village chief, as the new village now covered a much larger area. As new village might be composed of several smaller villages having different sub-cultures, misunderstandings arose among villagers.

New village laws sidelined traditional leaders, such as the village chief and temenggung, within Dayak society. The law required a village chief to be at least a junior high school graduate no older than 60 . This was quite different from previous Village Governance Law (UU 19/1965) which only required a primary school or equivalent education and did not restrict the age. This new regulation required qualifications that the existing traditional leaders lacked. Research conducted in the Bengkayang area published in 1975, for example, found that only one of 29 village chiefs had 6-years of primary education (Laporan survey 1975:38-40).

$9^{8}$ Prior to that many local communities had their own name for a village, for example banjar in Bali, nagari in West Sumatra, and kampung in parts of Sumatra and Kalimantan. These terms were revived again after the fall of the New Order.

99 'Memori Gubernur Kepala Daerah Tingkat I Kalimantan Barat, Haji Soedjiman, masa bhakti 1983-1988', 1988, p. 56, in: Library of West Kalimantan Governor's Office, Pontianak. 


\begin{tabular}{|l|c|c|}
\hline Number of households & Number of villages & $\begin{array}{c}\text { Percentage } \\
\text { of total villages }\end{array}$ \\
\hline$<50$ & 2,732 & 59.0 \\
\hline $51-100$ & 1,076 & 23.2 \\
\hline $101-300$ & 565 & 12.2 \\
\hline $301-500$ & 124 & 2.7 \\
\hline $501-1000$ & 92 & 2.0 \\
\hline$>1001$ & 43 & 0.9 \\
\hline Total & 4,632 & 100.0 \\
\hline
\end{tabular}

Table 6.12 Number of villages according to size before village reorganization

Source: 'Himpunan petunjuk pelaksanaan undang-undang nomor 5 tahun 1979 tentang pemerintahan desa tentang pembentukan, pemecahan dan penghapusan desa (penataan kembali wilayah desa)', 1988, p. 55, in: Library of West Kalimantan Governor's Office, Pontianak.

\begin{tabular}{|l|r|r|r|c|}
\hline District & $\mathbf{1 9 5 3}$ & $\mathbf{1 9 7 7}$ & $\mathbf{1 9 8 5}$ & $\begin{array}{c}\text { Percentage } \\
\text { change 1977-1985 }\end{array}$ \\
\hline Pontianak & 677 & 939 & 285 & -70 \\
\hline Sambas & 539 & 600 & 259 & -57 \\
\hline Sanggau & 917 & 1,174 & 224 & -81 \\
\hline Sintang & 1,039 & 1,145 & 237 & -79 \\
\hline Kapuas Hulu & 508 & 496 & 141 & -72 \\
\hline Ketapang & 310 & 309 & 120 & -61 \\
\hline Pontianak City & 21 & 22 & & -100 \\
\hline Total & 4,011 & 4,685 & 1,266 & -73 \\
\hline
\end{tabular}

Table 6.13 Number of villages before and after village reorganization by district (1953-1985)

Source: 'Kenjataan2 statistik Kalimantan Barat', 1953, p. 5, in: Archive Office of West Kalimantan, Pontianak; 'Kalbar membangun: Memori

Kadarusno Gubernur Kepala Daerah Tingkat I Kalimantan Barat 19721977', 1977, p. 18, 'Himpunan petunjuk pelaksanaan undang-undang nomor 5 tahun 1979 tentang pemerintahan desa tentang pembentukan, pemecahan dan penghapusan desa (penataan kembali wilayah desa)', 1988, p. 2, in: Library of West Kalimantan Governor's Office, Pontianak. 


\begin{tabular}{|c|c|c|c|c|}
\hline \multicolumn{2}{|c|}{ Sub-district } & \multirow{2}{*}{$\begin{array}{c}\text { Before } \\
29\end{array}$} & \multirow{2}{*}{$\begin{array}{c}\text { After } \\
15\end{array}$} & \multirow{2}{*}{$\frac{\text { Decrease (percentage) }}{48.3}$} \\
\hline \multirow{6}{*}{ 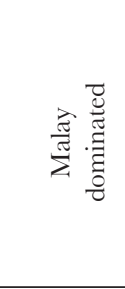 } & Pemangkat & & & \\
\hline & Tebas & 45 & 30 & 33.3 \\
\hline & Jawai & 26 & 20 & 23.1 \\
\hline & Sambas & 78 & 35 & 55.1 \\
\hline & Sejangkung & 26 & 14 & 46.2 \\
\hline & Teluk Keramat & 79 & 39 & 50.6 \\
\hline \multirow{5}{*}{ 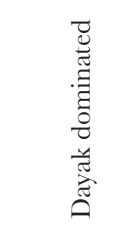 } & Samalantan & 52 & 15 & 71.2 \\
\hline & Bengkayang & 71 & 17 & 76.1 \\
\hline & Ledo & 66 & 17 & 74.2 \\
\hline & Sanggau Ledo & 28 & 12 & 57.1 \\
\hline & Seluas & 37 & 7 & 81.1 \\
\hline
\end{tabular}

Table 6.14 Number of villages before and after villages reorganization (Sambas) Note: This table excludes sub-districts with fewer than 20 villages.

Source: Soemardjan et al 1992.

Even after 20 years these criteria are still difficult to fulfil. Statistics in 1996 showed that of 1,402 village chiefs in the province only 55 per cent of them had education beyond elementary school. About 39 per cent of them only had elementary school education, 6 per cent did not finish elementary school, and 0.4 per cent had no formal schooling (Statistik potensi desa 1997:67). These new criteria were never strictly enforced due to lack of qualified personnel. However, the trend was towards more and more traditional village chiefs being replaced by a younger, better educated but less respected cohort of public servants. As a result, emotional ties which once existed between the village chiefs and villagers diminished.

The new regulation made the village chief's position dependent on the bureaucracy. One observer commented that the New Order had transformed the village chiefs from relatively independent positions to mere cogs in the machinery of bureaucracy. Prior to 1965, higher authorities had little contact with or interest in village-level governance (Antlöv:35, 135). The village head position (that is appointed or reappointed), for example, did not depend on the bureaucracy until implementation of the new law. The regime considered it to be in its best interest to co-opt and control this influential traditional leadership to avoid potential problems. 
In many places Dayaks reportedly listened more to informal traditional leaders (including the village chief) than to formal officials (Lontaan 1975:414-5; Soemardjan et al. 1992; Laporan survey 1975:43).

Similarly, the role of customary leaders or temenggung has declined quite rapidly. By 1982, West Kalimantan still had 849 temenggung. ${ }^{100}$ In 1987, the number of temenggung was further reduced to $801 .{ }^{101}$ At this point, the government decided not to fill the vacant positions when temenggung passed away or retired (Soemardjan et al. 1992:Chapter VI), and this added to attrition. Financial support given to the temenggung at the end of the $1970 \mathrm{~s}^{102}$ was discontinued later in an apparent effort to render the position unattractive. Unlike the village chiefs, the temenggung was not part of the bureaucracy, and was therefore dispensable. The government saw the customary leaders' role as increasingly irrelevant as it promoted the extensive use of formal or state laws and discouraged the application of customary laws. ${ }^{103}$ Furthermore, the adat structure, the raison d'être for the temenggung, had been significantly disrupted. ${ }^{104}$

Besides the government regulations, loss of popular trust in the village chief and temenggung had also contributed to their declining roles. For their own career advancement, many traditional leaders have repositioned themselves as tools of the regime. NGOs in the province have scrutinized the role of these leaders in land appropriation cases. Some

1 The largest concentrations were in Sanggau (215), followed by Ketapang (198), Sintang (139), Pontianak (104), Kapuas Hulu (102). None were found in Pontianak City ('Peningkatan pembinaan pemerintahan, pembangunan dan kemasyarakatan di daerah Kalimantan Barat', 1983, pp. 26-7, in: Library of West Kalimantan Governor's Office, Pontianak).

101 'Memori Gubernur Kepala Daerah Tingkat I Kalimantan Barat, Haji Soedjiman, masa bhakti 1983-1988', 1988, p. 59, in: Library of West Kalimantan Governor's Office, Pontianak.

${ }_{102}$ 'Kalbar membangun: Memori Kadarusno Gubernur Kepala Daerah Tingkat I Kalimantan Barat 1972-1977', 1977, p. 18, in: Library of West Kalimantan Governor's Office, Pontianak.

103 The state feared that customary laws would undermine state laws. Firstly, many aspects of customary laws were incompatible with state laws. Customary laws, for example, had different concepts of penalty and ownership. The penalty in Dayak customary law lacked the punishment aspects of the modern penal system. Under Dayak customary law, the penalty for misconduct was intended to restore the balance of nature which was affected by the misconduct. A traditional ceremony, animal sacrifices with a few pieces of stoneware and accessories would satisfy as a penalty, even for serious crimes such as murder (Lontaan 1975). The concept of ownership, a main source of dispute in many modern societies, also differed greatly from that of state laws. To confirm ownership, customary laws only needed confirmation or guarantee from the customary leaders. The customary laws did not need the paper proof that the modern legal system would require. The second reason for the government to discourage the application of the customary laws was the variety and non-codification of the laws, which could become sources of instability and other potential problems.

${ }^{104}$ A series of workshops conducted by the Dayak NGOs in 1999 estimated that about 70 per cent of adat structure had been undermined. Only in Kapuas Hulu and Sanggau districts did traditional structure and law still function well (Masiun 2000:13-4). 
have been persuaded to sign traditional lands away to government-approved projects after having been promised financial rewards or jobs. ${ }^{105}$ Others were tricked or coerced into delivering the traditional lands to the government (Djuweng 1992). A few who refused or had difficult relations with the government were made to retire or deterred from raising issues further. They were powerless before the regime and its security forces. Traditional leaderships across Indonesia suffered similar treatments during the New Order period.

\section{INTERNAL DIVISIONS AND LACK OF APPRECIATION}

Besides external influences explained above, Dayak's negative self perception undermined their own culture. Some Dayaks thought that aspects of their own culture were backward and incompatible with modernization and should therefore be abandoned. In 1946, Oevaang Oeray rejected the role of traditional leaders because he believed that they were a source of Dayak backwardness (DAO 1946c). He and other Dayak leaders blamed superstitious practices and lavish ceremonies for Dayak backwardness. ${ }^{106}$ Thirty years before the New Order introduced the village regrouping, Oeray had initiated a move to reorganize several villages into a centrally located community so that they could be made more economically viable and so that critical infrastructure, especially educational facilities, could be made more accessible and thereby benefit a greater number of people (Davidson 2002:97; Roekaerts 1985:7).

Many Dayaks lacked respect and appreciation for their own culture. Research on self-perception showed that the Dayaks rated themselves consistently low in almost all aspects of life compared to other ethnic groups (Alqadrie 1990; Roekaerts 1985). Many young Dayaks in the cities did not speak their own language because they considered Indonesian

\footnotetext{
105 Roekaerts 1985:28. The government also sometimes sent these leaders on a propaganda tour of plantations elsewhere to see their benefits (Dove 1986:16; Dayak leaders' memories 2005:7-8). In 1978, Donatus Djaman, a Dayak sub-district head of Meliau (Sanggau), was sent to North Sumatra to see the benefits of plantations. Upon returning he was ordered to identify 32 traditional leaders to be sent on the same propaganda tour. These leaders were sent to see the benefit of the plantations during the tour so that they would welcome the palm oil operations in their areas. Donatus Djaman, who showed reluctant support, was transferred from his post in Meliau (Dayak leaders' memories 2005:7-8). In 1982, 25 village chiefs from Sambas and 26 from Sintang were sent to view the plantation in South Kalimantan (Akcaya, 23-9-1982).

106 J.G. Oevaang Oeray, 'Nasibkoe Dayak', 1946, in: Private collection, Pontianak; Davidson 2002;97.
} 
or Malay to be more prestigious than their own languages. ${ }^{107}$ The identity change to Malay after converting to Islam was another indication that these Dayaks viewed other ethnic groups as better than themselves. A more recent observation on religious conversion in Nanga Pinoh (Sintang), Mulia Baru, Teluk Melano and Kendawangan (Ketapang) showed that the process of becoming Malay after conversion to Islam still continues. As soon as they professed Islam, Dayaks associated themselves with Malays (Julipin and Pius 1987:8). The Dayaks also have had relatively high rates of cross-cultural and cross-religious marriage compared to other ethnic groups. In many of these marriages, the Dayaks tend to embrace their partner's cultural and religious identity. ${ }^{108}$ Their inferiority complex could have been a result of centuries of neglect and repression. No doubt the New Order government's second-class treatment of Dayak culture exacerbated this negative self perception.

\section{SUMMARY}

This chapter has demonstrated the disadvantages of being Dayak during the New Order regime. In the executive, Dayak bureaucrats were denied top positions. In the legislature, Dayaks suffered a sudden setback after the coup in 1965. However, their representation in the legislature recovered after the 1977 election. Unfortunately, the higher proportion of Dayaks in the DPRD did not mean that they could use it to redress their being marginalized, and discussion of ethnic issues was still considered taboo by the regime. Furthermore, the DPRD was only a rubber stamp for the executive and rarely used its power and initiative to monitor the executive or change government policies.

Living conditions of many Dayaks in rural areas did not improve much during this period. Modern projects such as transmigration, timber exploitation, and plantation development had promised benefits to local people, but it brought problems as well. Transmigration was blamed for increasing unemployment among the local populations and for taking

107 Julipin and Pius 1987. Assimilation into the more powerful and prestigious culture has continued to take place. In Norway, for example, the inferior Sami were incorporated into the mainstream Norwegian group (Eriksen 1993:29). Other examples of the absorption of minorities into Malay in Southeast Asia have been mentioned in chapter two.

108 According to one local observation, Dayak women regarded males of other ethnic groups more favourably than they did Dayak males (Julipin and Pius 1987). 
away the traditional farming lands of many Dayaks. Younger and better educated Dayaks faced obstacles to entering public and private sectors, as those sectors were dominated by other ethnic groups.

From the social and cultural points-of-view, Dayak culture continued to be weakened by external and internal pressures. The introduction of major world religions has been a major factor and the regime's perception of Dayaks as isolated, primitive and backward broke down many of their traditions and beliefs. Many Dayaks suffered inferiority complexes due to a long history of being second-class citizens. The unfriendly New Order policies convinced some Dayaks that their culture was not on par with others, and some parts of it were primitive and detrimental to the Dayak development. Dayaks found it hard to express concerns about their loss of culture without being accused of encouraging ethnic discord. Overall, the Dayaks' marginalization is linked closely to their intense political activism immediately after the collapse of the New Order. 